Prethodno priopćenje UDK 316.7(045)

doi: $10.21464 /$ fi38409

Primljeno: 4. 4. 2018.

\title{
Krešimir Šimić
}

Sveučilište Josipa Jurja Strossmayera u Osijeku, Filozofski fakultet, Lorenza Jägera 9, HR-31000 Osijek ksimic@ffos.hr

\section{Interpretativna znanost o kulturi i postliberalna teologija}

\begin{abstract}
Sažetak
Kada se u drugoj polovici devetnaestoga stoljeća pokušala konstituirati, znanost o kulturi (Science of Culture) predstavljala se je kao reformska znanost. Ona je bila reformska ponajprije u smislu emancipacije od metafizike i teologije, ali također i u smislu društvenog napretka (E. B. Tylor). Znanost o kulturi, koja se pokušala zasnovati kao kohezijsko mjesto za sve društveno-humanističke znanosti i postati reformska, postala je u konačnici interpretativna znanost (C. Geertz). Tako shvaćena znanost o kulturi također ima reformatorski afinitet. U radu se - nakon osvrta na devetnaestostoljetnu znanost o kulturi-donose temeljne odrednice Geertzove teorije kulture i postliberalne teologije, koja se uvelike zasnovala upravo na Geertzu. Konačno, izlaže se reformski potencijal interpretativne znanosti o kulturi i postliberalne teologije.
\end{abstract}

\section{Ključne riječi}

znanost o kulturi, interpretativna znanost, Clifford Geertz, postliberalna teologija, reforma

I.

Parafrazirajući početne riječi Manifesta komunističke partije (Manifest der Kommunistischen Partei, 1847.), Peter Sloterdijk je knjigu Svoj život promijeniti moraš (Du mußt dein Leben ändern, 2009.) započeo konstatacijom:

»Bauk kruži zapadnim svijetom - bauk religije. $\ll^{1}$

Žele li biti »razumne«, smatra Sloterdijk, religije moraju tražiti savezništvo sa sekularnom civilizacijom i njezinom znanosti o kulturi, koja treba po-

1

Peter Sloterdijk, Svoj život promijeniti moraš, preveo Kiril Miladinov, Sandorf \& Mizantrop, Zagreb 2015., str. 11. Iako je Sloterdijkova misao krajnje zaoštrena, u nekoj mjeri odražava uvid dvadesetostoljetnih sociologa religije koji su ustvrdili da postprosvjetiteljski projekti zasnivanja kulture koja bi »izgurala« religiju nisu u potpunosti uspjeli. Pokazalo se da sociolozi koji su slijedili K. Marxa, M. Webera i É. Durkheima nisu bili u pravu predviđajući da će religije iščeznuti ili se, u najmanju ruku, ako već nije moguće zatrti nagon za numinoznim, povući u sferu privatnog. Međutim, kada P. Sloterdijk tvrdi da bauk religije kruži zapadnim svijetom, on ipak smatra da to nije bauk povratka religije jer religije ne postoje. Postoje samo pogrešno razumljeni sistemi spiritualnog vježbanja. Ono što se uistinu vraća i što zaslužuje pozornost zapravo je imunosni ustroj ljudskog bića. Nakon višestoljetnih eksperimenata s novim oblicima života iskristalizirao se uvid, smatra P. Sloterdijk, da ljudi ne egzistiraju samo u »materijalnim okolnostima« nego i u simboličkim imunosnim sistemima i pod plaštevima obreda. »Religija « je nesretno sročen pojam koji nadmašuje samo hiperavetinja »kultura« - zaključuje u svom prepoznatljivom stilu P. Sloterdijk. Vidi: ibid., str. 13-14. 
stati istinska moderatorica globalne ekumene. Treba nam stoga, zaključuje Sloterdijk na kraju svoje knjige Božja revnost (Gottes Eifer, 2007.), »transkulturalno uvjerljiva formulacija opće teorije kulture «. ${ }^{2}$ Očito je: Sloterdijk progovara, doduše na sasvim originalan način, ${ }^{3}$ iz one zapadnjačke tradicije koja je upravo znanost o kulturi držala ne samo kohezijskim mjestom za sve društveno-humanističke znanosti nego i reformskom znanosti - odnosno svojevrsnom moderatoricom ekumene. Iako je naznačena tendencija bila snažno prisutna u njemačkoj (Geisteswissenschaften), pa u nekoj mjeri i u ruskoj kulturnoj tradiciji (antropologia), ${ }^{4}$ njezino pojavljivanje i razvoj u američkobritanskom milieu iznjedrio je interpretativnu znanosti o kulturi (C. Geertz) - čija je definicija kulture i metodološka invencija snažno utjecala na brojne društveno-humanističke projekte.

Edward B. Tylor, pionir američko-britanskog zasnivanja znanosti o kulturi (Science of Culture), isticao je da su metafizika i teologija glavna prepreka u istraživanju »zakona ljudske prirode« - koja bi trebala biti u srži znanosti o kulturi. ${ }^{5}$ Nakon što je ustvrdio da se metafizika i teologija trebaju odbaciti, istaknuo je primjer »slobodne volje« koja se, nastavlja Tylor, u metafizičko-teologijskoj tradiciji tumači kao djelovanje bez razloga, natprirodno djelovanje, predestinacija i sl. ${ }^{6}$ Zatim je zaključio da »moramo brzo pobjeći od transcendentalne filozofije i teologije da bismo započeli obećavajuće putovanje preko praktičnijeg područja«. ${ }^{7}$ Odmah potom, pozivajući se na »dokaze vlastite svijesti svakog čovjeka«, napominje da nitko neće zanijekati da nedvojbeni i prirodni zakoni određuju ljudsko djelovanje. Dakle, Tylor kao polazište znanosti o kulturi uzima pretpostavku postojanja »prirodnih uzroka i posljedica« (natural cause and effect) i »zakone ljudskog uma« (the laws of mind $).{ }^{8}$ Konačno, znanost o kulturi, razumijevajući tijek ljudske povijesti, prema Tyloru, pomaže ne samo u predviđanju bolje budućnosti nego i omogućava da svijet učinimo »boljim «. ${ }^{9}$ Stoga je »znanost o kulturi u bîti znanost reformatora «. ${ }^{10}$

Da je znanost o kulturi znanost reformatora, mislio je i Franz Boas - ali na pretpostavkama drugačijim od Tylorovih i »neoevolucionističkih «. ${ }^{11}$ Naime, Boas je zastupao mišljenje da su kulturne prakse razumljive samo u posebnom kulturnom kontekstu i da se ne mogu protumačiti pomoću evolucijskih stupnjeva. ${ }^{12}$ Evolucijski pristup - o kojemu je Tylor pisao u uvodnim stranicama Primitivne kulture - pretpostavlja da tijek kulturnih promjena slijedi određene zakone koji su svugdje isti. Međutim, istaknuo je Boas, čim priznamo da hipoteza o »jednoobraznoj evoluciji« (uniform evolution) treba biti prvo dokazana da bismo je primijenili, ${ }^{13}$ cijela struktura gubi svoj temelj. ${ }^{14}$ Evolucijski sustavi stoga nisu teorije izvedene iz etnografskih podataka, nego su to pretpostavke nametnute građi. Riječ je o svojevrsnoj logičkoj pogrešci: hysteron - proteron. Boasovu osnovnu pretpostavku - da kulturu treba razumjeti pomoću podrobnih istraživanja brojnih kultura - preuzeo je prvi naraštaj američkih antropologa: Alfred Kroeber, Ruth Benedict, Edward Sapir, Margaret Mead i dr. ${ }^{15}$

Iako je od šezdesetih godina dvadesetog stoljeća znanosti o kulturi svojstvena raznovrsnost, $i$ to često nepomirljivih teorijskih stajališta, u žarište dolazi simbolična bît kulture. Promjena stajališta u radovima Claudea Lévi-Straussa, Victora Turnera, Mary Douglas, očita je. ${ }^{16}$ Lévi-Strauss smatra da unatoč površnim različitostima, komunikacijske razmjene na području krvnog srodstva, mita i jezika proizlaze iz prilično malog broja temeljnih oblika ili »dubinskih struktura«. Te strukture odražavaju univerzalnu gramatiku kulture ukorijenjenu u podsvjesnim svojstvima ljudskog uma i predstavljaju načela pomoću 
kojih ljudi prave klasifikacije. Lévi-Strauss stoga kulturu vidi kao simbolični izraz ljudskog uma. ${ }^{17}$ Turner simboličku prirodu kulture tumači unutar dinamike društvenog života. Simboli se, prema njemu, koriste i značenja se

Peter Sloterdijk, Božja revnost, prevela Nadežda Čačinovič, Bosansko narodno pozorište, Zenica 2013., str. 237.

3

P. Sloterdijk se, naime, poduhvatio »prijevoda« religijskog, duhovnog i etičkog na jezik i optiku opće egzercicijske teorije. Tu je teoriju razumio kao prosvjetiteljski poduhvat u čijem je temelju interes dvostrukog očuvanja: »... s jedne se strane opredjeljuje za kontinuum kumulativnog učenja, koje zovemo prosvjetiteljskim te s kojim mi današnji, usprkos svim glasinama o najnovijim 'post-sekularnim' okolnostima, nastavljamo kao s programom učenja modernog doba koji se proteže kroz već četiri stoljeća; s druge se strane on drži tisućljetnih niti koje nas vežu za rane manifestacije čovjekova znanja o vježbanju i prožimanju dušom, pretpostavimo li da smo spremni na njih se eksplicitno nadovezati.« Vidi: P. Sloterdijk, Svoj život promijeniti moraš, str. 16. P. Sloterdijk - da se poslužim njegovim riječima - zagovara stvaranje globalne ko-imunosne strukture $u$ koju se uključuju pojedinačne kulture, partikularni interesi i lokalne solidarnosti. Tâ bi struktura trebala zadobiti planetarni format. Tako bi bespomoćna cjelina postala protektivno sposobno jedinstvo. Na mjesto romantike bratstva stupila bi kooperativna logika. Ljudi bi postali suradnici u projektu oblikovanja globalnog imuniteta. Taj uvid nameće pak makro-strukturu globalnih imunizacija: ko-imunizam. Takva se struktura zove civilizacija. Njezina »redovnička pravila« kodirat će antropotehnike koje su u skladu s egzistencijom u kontekstu svih konteksta. Vidi: ibid., str. 490.

4

U njemačkoj kulturnoj tradiciji »duhovne znanosti« (Geisteswissenschaften) - znanost o državi, gospodarstvu, odgoju, umjetnosti, jeziku, religiji, filozofiji, znanosti - konstituirale su se u svojevrsnoj emancipaciji od metafizike i teologije. Za njih je bitan povijesni svijet. Izvor je toga svijeta povijesni um, stoga je - smatra W. Dilthey - zadatak utemeljenja »duhovnih znanosti« kritika povijesnog uma, a ne kritika čistog uma (Grundlegung der Wissenschaften vom Menschen der Gesellschaft und der Geschichte, 1865.-1880.). Početkom 20. stoljeća pojam »duhovnih znanosti« pokušalo se zamijeniti pojmom »kulturnih i povijesnih znanosti« (H. Rickert) ili »historijsko-etičkih znanosti« (E. Troeltsch). U Rusiji se u šezdesetim godinama 19. stoljeća (P. L. Lavrov, Chto takoe antropologia?, 1860.) javila ideja da antropologija bude znanost koja će integrirati sva znanja o čovjeku i društvu. Vidi: Alfred G. Meyer, »Historical Notes on
Ideological Aspects of the Concept of Culture in Germany and Russia«, u: Alfred L. Kroeber, Clyde Kluckhohn, Culture: A Critical Review of Concepts and Definitions, Peabody Museum of American Archaeology and Ethnology, Harvard University Press, Cambridge 1952., str. 207-212, str. 210.

E. B. Tylor je prvo poglavlje svoje knjige Primitivna kultura (Primitive Culture, 1871.) naslovio upravo »Znanost o kulturi« (The Science of Culture). Njegova definicija kulture - koja je »u jednom širem, etnografskom smislu, cjelina koja uključuje znanje, vjerovanje, umjetnost, moral, zakon, običaje i mnoge druge sposobnosti i navike koje čovjek stječe kao član društva« (Edward Brunett Tylor, Primitive Culture: Researches into the Development of Mythology, Philosophy, Religion, Language, Art and Custom, J. Murray, London 1871., str. 1) - postala je (doduše, tek pedesetak godina nakon objavljivanja spomenute knjige) neizostavna $u$ američkim i britanskim rječnicima. Vidi: A. L. Kroeber, C. Kluckhohn, Culture, str. 9. Nedvojbeno je da je na E. B. Tylora i njegovo korištenje pojma kultura znatno utjecao G. E. Klemm. Naime, sâm E. B. Tylor u svojim se Istraživanjima (Researches, 1865.) na kraju prvog poglavlja (str. 13) referira na Klemmova djela Allgemeine Cultur-geschichte der Menscheit (kompletirano desetim sveskom 1852.) i dvotomno Allgemeine Culturwissenschaft (1854.1855.). Vidi: ibid., str. 10, 25. Razlog zašto je Tylorova definicija kulture, koja uostalom i nije bila toliko originalna, imala tako snažan utjecaj ne leži toliko u njegovom iznimnom uvidu $i$ pronicljivosti, koliko leži u tome da je upravo on, određujući njezin predmet, zasnovao jednu znanost o kulturi. Vidi: ibid., str. 150

6

E. B. Tylor, Primitive Culture, str. 3 .

Ibid.

Ibid.

9

Edward Brunett Tylor, Researches into the Early History of Mankind and the Development of Civilization, University of Chicago Press, Chicago 1964., str. 539.

10

Ibid.

11

Na Tylorovu (i Morganovu) reformatorskom tragu svoje viđenje znanosti o kulturi zasni- 
stvaraju u javnim, društvenim razmjenama. Simboli imaju posebna svojstva: oni su snažni sažeci značenja, njihova su značenja višestruka i razlikuju se za različite članove društva. Razumijevanje kulturnoga života pretpostavlja izdvajanje simbola, određivanje njihova značenja i prikazivanje načina na koji simboli djeluju unutra posebnog, dinamičnog kulturnog konteksta. ${ }^{18}$ Douglas analizira kako ljudi izražavaju simbolične sustave i društvene institucije da bi stvorili značenjske i jedinstvene iskaze o tome tko su. ${ }^{19}$ Da je temeljna zadaća znanosti o kulturi upravo interpretativna; da znanost o kulturi nije eksperimentalna znanost koja traga za zakonitostima, već interpretativna disciplina koja traga za značenjem - na inovativan i iznimno sugestivan način tvrdio je Clifford Geertz. ${ }^{20}$

\section{II.}

Geertz se suprotstavlja Tylorovu viđenju (koje naziva prosvjetiteljsko) prema kojemu je čovjek u potpunosti dio prirode i sudjeluje u općoj jednoobraznosti sklopa koju je »prirodna znanost « (natural science) potaknuta Baconom i vođena Newtonom u njoj otkrila. ${ }^{21}$ Ta ideja, napominje Geertz, nije nova: poznat je pojam consensus gentium (mišljenje prema kojemu se svi ljudi slažu da su neke stvari dobre, stvarne, pravedne) koji nije karakterističan samo za prosvjetiteljstvo nego i za druga vremena. ${ }^{22}$ Pristup koji zagovara Tylor i autori koji prihvaćaju načelo jednoobraznosti (uniformitarianism) pretpostavlja: 1) da su predočene univerzalije supstancijalne univerzalije, a ne prazne kategorije; 2) da su utemeljene u posebnim biološkim, psihološkim ili sociološkim procesima; i 3 ) da mogu biti uvjerljivo obranjene kao bitni elementi definicije ljudskosti u odnosu na kulturne različitosti koje su drugorazredne. ${ }^{23}$ Međutim, smatra Geertz, prva pretpostavka ne može biti ispunjena jer je logički proturječno tvrditi da su, primjerice, »religija«, »brak« i »vlasništvo« empirijske univerzalije i istodobno im pripisivati značajnu specifičnu sadržinu. ${ }^{24}$ To onda otežava i ispunjenje druge pretpostavke. Štoviše, ističe Geertz, kada se jednom biološko, psihološko i sociološko odvoje od kulture, iznimno je teško ponovno ih spojiti. ${ }^{25}$ Strategija »invarijantnih referentnih točaka« (invariant points of reference) zapravo nije nikakva integracija kulturnih i supkulturnih nivoa, nego puka korelacija i to odvojenih rezultata. Teorija nivoa, čak i kad se poziva na »invarijantne referentne točke«, ne može konstruirati istinski funkcionalne veze između kulturnih i ne-kulturnih činjenica, nego samo manje ili više uvjerljive analogije i sugestije. Stoga, ističe Geertz, treba tražiti sistemske odnose među različitim pojavama, a ne »bitne« identičnosti među njima. "Stratigrafsko« (stratigraphic) shvaćanje odnosa među različitim aspektima ljudske egzistencije treba zamijeniti sintetičkim - što podrazumijeva da se s biološkim, psihološkim, sociološkim i kulturnim činjenicama može postupati kao s varijablama unutar jedinstvenoga sistema analize. Riječ je o integriranju različitih tipova teorija i pojmova tako da se mogu oblikovati smislene tvrdnje koje obuhvaćaju izolirane rezultate različitih disciplina. ${ }^{26}$

Jasno je: budući da odbacuje kategorije "prirodnih uzoraka i posljedica« (natural cause and effect) i "zakona ljudskog uma" (the laws of mind), za Geertza znanost o kulturi nije, kao što je bila za Tylora, predviđalačka (predictive). ${ }^{27}$ Međutim, to ne znači da ona i nadalje nije znanost reformatora. Doduše, ne više u smislu da pomoću nje možemo razumjeti tijek ljudske povijesti, pa stoga i svijet učiniti »boljim«, ni u smislu da pomoću nje možemo odgovoriti na naša temeljna pitanja, nego da nam učini dostupnima odgovore drugih ljudi na temeljna pitanja i tako ih uključi u dostupan dokument o tome 
što je rekao čovjek. ${ }^{28}$ Da bi došao do takvog cilja - ili, točnije, jer je takav cilj naciljao - Geertz je kulturu definirao na nov način te je posljedično razvio i novu metodu.

\section{III.}

Pojmovni ćorsokak u koji nas je dovelo moderno značenje pojma kulture, napominje Geertz, očit je u jednom od boljih uvoda u antropologiju: Ogleda-

vali su - da istaknem glasovitije - Leslie White, Julian Steward i Marvin Harris. Oni su kulturne promjene povezivali s različitim područjima materijalnog života. Drugim riječima, »neoevolucionisti« su, za razliku od idealističkih i povijesnih tumačenja, uzroke promjena tumačili materijalistički (promjene u načinu proizvodnje).

12

Jerry D. Moore, Uvod u antropologiju, prevela Gordana V. Popović, Naklada Jesenski i Turk, Zagreb 2002., str. 56.

13

U pokušaju rekonstruiranja povijesti ljudske kulture, E. B. Tylor oslonio se na dva načela: jednoobraznost (uniformitarianism) i prežitak (survivals), odnosno odrazi ranijih stupnjeva kulture. Osnova Tylorova poimanja jednoobraznosti tvrdnja je da su procesi kulture slični kod svih ljudi, bez obzira gdje i kad oni živjeli, zbog »zakona ljudskog uma«. Vidi: J. D. Moore, Uvod u antropologiju, str. 158. Budući, dakle, da su mentalni procesi kod ljudi univerzalni, ljudske zajednice razvijaju kulturu na temelju "gotovo istovrsnih obrazaca« kojima je svojstven napredak i izražavaju se u evoluciji kulture. Vidi: ibid., str. 27. Odupirući se suvremenoj (devetnaestostoljetnoj) kritici esencijalizma i svojevrsnom »čitanju« Biblije koje je tada bilo nešto poput khunovske paradigme za izučavanje kulture, evolucionističke teorije $\mathrm{u}$ Tylorovo doba isticale su da ljudske razlike proizlaze iz različitog stadija kulturnog razvitka. Vidi: George Stocking Jr., Race, Culture and Evolution: Essays in the History of Anthropology, Free Press, New York 1968., str. 71. Na taj su način pokušale dokinuti teološko učenje o esencijalističkom jedinstvu čovjeka, oduprijeti se suvremenoj kritici esencijalizma koja je dovela do dubokih epistemoloških i etičkih previranja te ujedno biti sredstvo u ostvarivanju »društvenog napretka $\ll$.

14

Franz Boas, »The Methods of Ethnology«, American Anthropologist 22 (1920) 4, str. 311-321.

15

J. D. Moore, Uvod u antropologiju, str. 56-57. 16

Ibid., str. 279-280.
17

Usp. Claude Lévi-Strauss, Anthropologie structurale, Plon, Paris 1973.

18

Usp. Victor Turner, The Ritual Process: Structure and Anti-Structure, Cornell University Press, New York 1969.

19

Usp. Mary Douglas, Natural Symbols: Explorations in Cosmology, Routledge, London, New York 1996.

20

Usp. Clifford Geertz, The Interpretation of Cultures, Basic Books, New York 1973. David M. Schneider jedan je od najprominentnijih autora novog pokreta koji se često nazivao "simbolička antropologija«, iako je sâm C. Geertz preferirao naziv »interpretativna antropologija«. D. Schneider svoju je »viziju« kulture (kultura je sistem simbola i značenja koji su »osnovne premise koje kultura postavlja za život«; te premise omogućuju da se dijelovi drže na okupu, definiranje i razlikovanje dijelova, formiranje reda, strukturiranje svijeta itd.) izložio u uvodu svoje knjige American Kinship: Cultural Account (1968.). $\mathrm{Na} »$ kontinentu«, ovaj su pristup najopširnije tumačili Louis Dumont i Volker Gottowik.

21

C. Geertz, The Interpretation of Cultures, str. 34. 22 Ibid., str. 38-39.

23

Ibid., str. 39.

24

Ibid., str. 39-40.

25

Ibid., str. 41.

26

Ibid., str. 41-44. C. Geertz piše o »zamućenim žanrovima« (blurred genres). Vidi: Clifford Geertz, Local Knowledge, Basic Books, New York 1983., str. 19-36.

27

C. Geertz, The Interpretation of Cultures, str. 26.

28

Ibid., str. 30 . 
lu za čovjeka (Mirror for Man, 1944.) Clydea Kluckhohna. ${ }^{29} \mathrm{U}$ tom je djelu - navodi Geertz - Kluckhohn definirao kulturu kao: 1. »ukupni način života jednog naroda «; 2. »društveno nasljeđe koje pojedinac prima od svoje grupe«; 3. »način mišljenja, osjećanja i vjerovanja«; 4. »apstrakt ponašanja«; 5. teoriju koju antropolog razvija s obzirom na način na koji se grupa ljudi ponaša: 6. »spremište akumuliranog znanja«; 7. »skup standardiziranih odnosa prema problemima koji se ponavljaju«; 8. »naučeno ponašanje«; 9. mehanizam za normativno reguliranje ponašanja; 10. »skup tehnika prilagođavanja izvanjskom okruženju i drugim ljudima«; 11. »talog povijesti«; i, možda u očaju, okrenuvši se usporedbama: kao mapu, sito i matricu..$^{30} \mathrm{U}$ usporedbi s ovakvom vrstom teorijske difuznost, napominje Geertz, čak i donekle skučen i ne sasvim standardan pojam kulture, koji je bar iznutra koherentan i, što je važnije, koji tvrdi nešto što se može definirati, predstavlja napredak. ${ }^{31}$ Odmah zatim Geertz u uvodnom eseju Podroban opis: prema interpretativnoj teoriji kulture (Thick Description: Toward an Interpretative Theory of Culture) svoje glasovite knjige Interpretacija kultura (The Interpretation of Cultures, 1973.) piše:

»Pojam kulture za koji se zalažem i čiju će korisnost sljedeći eseji nastojati pokazati, u biti je semiotički. Vjerujući, zajedno s Maxom Weberom, da je čovjek životinja koja visi u mrežama značenja što ih je sam spleo, kulturu doživljavam poput tih mreža, pa stoga njihova analiza ne treba biti eksperimentalna znanost koja traga za zakonitostima, nego interpretativna znanost $u$ potrazi za značenjem. $\ll^{32}$

Naglasak na semiotici dokida primat tehnologije ili infrastrukture, što su isticali materijalisti (L. White i M. Harris), ${ }^{33}$ ili bilo koje drugo poimanje »dodira« prirode i kulture. Samo, treba istaknuti, Geertz se opire poistovjećivanju semiotike, u općem smislu kao znanosti o znakovima, sa strukturalizmom. ${ }^{34}$ Da bi bila korisna, semiotika se, smatra Geertz, mora pomaknuti od razmatranja znakova kao sredstava komunikacije, kôda koji treba dešifrirati, prema razmatranju znakova kao modusa mišljenja, idioma koji treba interpretirati. Ono što trebamo nije nova kriptografija, nego nova dijagnostika - znanost koja može odrediti značenja stvari za život koji ih okružuje. ${ }^{35}$ Smisao semiotičkoga pristupa kulturi u tome je da nam pomogne da uđemo u konceptualni svijet $\mathrm{u}$ kojemu žive subjekti i tako nam omogući komunikaciju. ${ }^{36}$

Geertz je kao osnovni metodološki postupak interpretativne znanosti o kulturi istaknuo »podrobni opis« (thick description). ${ }^{37}$ Što se tiče znanstvene nomenklature, Geertz smatra da repertoar općih akademskih pojmova: »ugradnja«, $»$ racionalizacija «, »simbol«, »ideologija «, »etos«, »revolucija«, »identitet«, »metafora «, »struktura «, »ritual«, »pogled na svijet«, »djelatnik «, »funkcija «, »sveto« i, naravno, »kultura« - jednostavno treba utkati u tkivo etnografije podrobnog opisa da bi se puka događanja učinila znanstveno elokventnima. ${ }^{38}$ Cilj je pak podrobnog opisa da se iz sitnih, gusto tkanih događaja izvuku krupni zaključci ${ }^{39}$ Razmotrimo još nakratko osnovne Geertzove tvrdnje, u njegovu opusu uvijek ilustrativno ocrtane etnografskim primjerima.

Kulturni obrasci, tvrdi Geertz, imaju dvostruki intrinzičan aspekt: oni daju značenje, odnosno objektivnu konceptualnu formu društvenoj i psihičkoj realnosti - $\mathrm{i}$ to tako što istodobno oblikuju sebe prema njoj i nju prema sebi. ${ }^{40}$ Upravo međusobna izmjenjivost modela za nešto (models for) i modela nečega (models of) koju omogućava simbolička formulacija distinktivno je obilježje naše mentalnosti. ${ }^{41}$ Iz takve perspektive, Geertz kritizira kognitivističku antropologiju koja je nastala kao korekcija biheviorističkih i idealističkih pristupa kulturi, a prema kojoj mentalni fenomeni mogu ili trebaju biti analizirani formalnim metodama sličnim onima u matematici ili logici. Zato što se 
simboli (ekstrinzični izvori informacija u okviru kojih se ljudski životi mogu oblikovati) ${ }^{42}$ i značenja nalaze između društvenih aktera, a ne u njima (u njihovim glavama), Geertz smatra da je kognitivni pristup Warda Goodenougha

29

Ibid., str. 4.

30

Ibid., str. 4-5.

31

Iako definicije ne utvrđuju zapravo ništa, napominje C. Geertz, one same po sebi, ako su pažljivo sklopljene, omogućavaju korisno usmjeravanje i preusmjeravanje mišljenja, tako da njihovo daljnje »raspakiranje« može predstavljati uspješan način razvoja i kontrole novog pravca istraživanja. Definicije imaju korisnu vrlinu eksplicitnosti: one obvezuju sebe na način na koji to ne radi diskurzivna proza, koja je uvijek sklona argument zamjeniti retorikom. Vidi: ibid., str. 90-91.

32

Ibid., str. 5. U eseju »Religija kao kulturni sistem« (»Religion as Cultural System«), C. Geertz donosi sljedeću definiciju kulture: »Kultura označava povijesno prenošen obrazac značenja utjelovljenih u simbolima sistem naslijeđenih pojmova izraženih simboličkim formama pomoću kojih ljudi prenose, čuvaju i razvijaju svoje znanje o životu i stavove prema njemu.« [»... it denotes an historically transmitted pattern of meanings embodied in symbols, a system of inherited conceptions expressed in symbolic forms by means of which men communicate, perpetuate, and develop their knowledge about and attitudes toward life.«]. Vidi: ibid., str. 89.

33

L. White snažno je zastupao teoriju kulturne evolucije koja se »ni najmanje ne razlikuje od načela koja je Tylor iznio u knjizi Antropologija (Anthropology, 1881.), iako se, dakako, razvoj, izraz i prikaz teorije može u nekim pitanjima razlikovati«. Vidi: Leslie White, The Evolution of Culture: The Development of $\mathrm{Ci}$ vilization to the Fall of Rome, McGraw-Hill, New York 1959., str. ix. Uz to, L. White je zagovarao opću znanost o kulturi, koju je nazvao kulturologijom (culturology). Usp. Leslie White, The Science of Culture: A Study of Man and Civilization, Grove Press, New York 1949. Ona se treba baviti strukturom i djelovanjem kulturnih sustava. Usp. L. White, The Evolution of Culture, str 16. Nju ne zanimaju posebne kulture, osim kao primjeri općenitoga. Kultura se promatra kao područje fenomena, kao da postoji sama za sebe, neovisna o ljudskoj vrsti. Usp. ibid. Kulturologija se, dakle, bavi općim načelima koja definiraju i predviđaju odnose unutar kulturnih fenomena. M. Harris u uvodu svoje knjige Uspon antropoloških teorija: Povijest teorija kulture (The Rise of Anthropological Theory: A History of Theories of Culture, 1968.) kulturni materija- lizam opisuje kao sociokulturnu istoznačnicu Darwinovoj selekciji i odmah ga određuje kao ne-idealističku i evolucijsku teoriju. U kulturnom materijalizmu nema pozivanja na ljudsku prirodu, jedinstvenost različitih kultura, temeljne vrijednosti, dubinske strukture i sl Umjesto toga, M. Harris razvija načelo tehnološko-okolišnog i tehnološko-ekonomskog determinizma. Prema tom načelu, slične tehnologije primijenjene u sličnim okruženjima sklone su proizvesti slične organizacije rada u proizvodnji i raspodjeli, a te su kategorije sklone uspostavljanju sličnih vrsta društvenih skupina koje opravdavaju i koordiniraju svoja djelovanja pomoću sličnih sustava vrijednosti i vjerovanja. Prevedeno u istraživačku strategiju, načela tehnološko-okolišnog i tehnološko-ekonomskog determinizma daju prednost istraživanju materijalnih uvjeta sociokulturnog života, jednako kao što načelo prirodnog odabira daje prednost istraživanju uspješnosti diferencijalne reprodukcije. Usp. Marvin Harris, The Rise of Anthropological Theory: A History of Theories of Culture, Thomas Y. Crowell, New York 1968., str. 4. Prema M. Harrisu, razumijevanje kulturnih obrazaca najprije zahtijeva objašnjenje fenomena $u$ kontekstu infrastrukture - međudjelovanje kulture i prirode izraženo dimenzijama poput preživljavanja, nastanjivanja, stanovništva, demografije itd. - a potom razumijevanje kako te promjene preoblikuju strukturu (ekonomski procesi) i superstrukturu (simboli). M. Harris tom se strategijom služio pri evolucijskom nacrtu povijesti svijeta. Usp. Marvin Harris, Cultural Materialism: The Struggle for a Science of Culture, Random House, New York 1979., str. 79-113.

34

C. Geertz, Local Knowledge, str. 12. C. Geertz strukturalizam drži hiperracionalističkom antropološkom paradigmom te ga stoga odbacuje i zagovara fleksibilnu (flexible) i situacijsku (situational) hermeneutiku. Usp. Philip Smith, »The Balinese Cockfight Decoded: Reflections on Geertz and Structuralism «, u: Jeffrey C. Alexander, Philip Smith, Matthew Norton (ur.), Interpreting Clifford Geertz, Palgrave Macmillan, New York 2011., str. 17-32, str. 19, doi: https://doi.org/10.1057/9 780230118980

35

C. Geertz, Local Knowledge, str. 120.

36

C. Geertz, The Interpretation of Cultures, str. 24. 37

Pojmove »grub« (thin) i »podroban« (thick), ističe sâm C. Geertz, preuzeo je od G. Ryla. 
i »novih etnografa« redukcionistički i lažno formalistički. ${ }^{43}$ Kada kažemo, napominje Geertz, da kulturu čine društveno ustanovljene strukture značenja u okviru kojih ljudi čine stvari kao što su signaliziranje zavjera i uključivanje u njih ili opažanje poruga i odgovaranje na njih, ne znači da time tvrdimo da je to psihički fenomen, osobitost nečijeg duha, osobnosti, kognitivne strukture ili bilo čega drugog. ${ }^{44}$ Ono što na mjestu kakav je, primjerice, Maroko najviše sprječava nâs koji smo odrasli u zapadnoj kulturi da shvatimo što ljudi rade, nije toliko nepoznavanje načina funkcioniranja kognicije koliko nedostatak poznavanja imaginativnog svijeta u okviru kojega njihovi čini predstavljaju znakove - tvrdi Geertz. ${ }^{45}$ Na primjeru Pajdžanova nesretnog pogreba na Javi, Geertz je nastojao pokazati da statički funkcionalizam, bio on sociološki ili sociološko-psihološki, ne razlikuje logičko-značenjsku integraciju od kauzalno-funkcionalne integracije zato što ne razumije da kulturna struktura nije samo odraz društvene strukture, nije ni društvena struktura samo odraz kulturne strukture, nego su one nezavisne, a ipak međuzavisne varijable. ${ }^{46}$

Nama stoga treba, napominje Geertz, nešto više od »lokalnog znanja« (local knowledge). Za Geertza je to »način pretvaranja različitih varijanti u njihove međusobne komentare, da jedna osvjetljava ono što druga zatamnjuje $\ll{ }^{47} \mathrm{Za}$ tô ne postoji gotova metoda, nego »nagomilana dosjetljivost« (accumulated cunning) ${ }^{48}$ Trebamo dovoditi različite načine registriranja iskustva i izricanja stvari u suodnos da bismo ih vidjeli kao manje zagonetne negoli kad se čine dok ih promatramo zasebno. To je, ističe Geertz, upravo obrnuto od misli Georgea Santayane da čovjek uspoređuje samo kad nije sposoban prodrijeti u srž. Kroz uspoređivanje, i to neusporedivog, dopiremo do te neke srži - tvrdi Geertz. Jedine do koje možemo doprijeti. Uspoređivanje neusporedivog ono je na što discipline posvećene deskriptivnom objašnjavanju imaginativnih oblika troše većinu svog vremena. Upravo to, ističe Geertz, nudi više u oblikovanju našeg puta kroz nedoumice od navodno »znanstvenijih« (more 'scientific') pothvata, u kojim se sve mora stjecati u jednoj točki. ${ }^{49}$ Kao međusobno isprepleten sistem znakova podložnih tumačenju, kultura nije nešto čemu se društveni događaji, ponašanja, institucije ili procesi mogu kauzalno pripisivati: ona je kontekst, nešto unutar čega se oni mogu pojmljivo - to jest, podrobno - opisati. ${ }^{50}$

\section{IV.}

Geertz je ne samo ikonička figura tzv. kulturnog okreta (cultural turn) nego je, spomenuo sam, utjecao na brojne društveno-humanističke projekte. ${ }^{51}$ Iako su potaknuti raznim autorima (Barthovom oštrom kritikom teološke koncepcije analogia entis, Wittgensteinovim konceptom jezičnih igara, moralnom filozofijom Alasdaira MacIntyrea, kritikom kartezijanskog cogita Gilberta Rylea, sociologijom religije Petera Bergera, književnom teorijom Ericha Aurebacha), na postliberalne teologe (čije se teološke tendencije često nastoje obuhvatiti nazivima Yale School ili »narativna teologija $)^{52}$ presudno je utjecao upravo Geertz. Dovoljno je pročitati »programatsku« knjigu Priroda doktrine (The Nature of Doctrine, 1984. ${ }^{53}$ Georgea Lindbecka i Tipovi kršćanske teologije (Types of Christian Theology, 1992.) Hansa Freija - dvaju korifeja postliberalnog teološkog pokreta. ${ }^{54} \mathrm{U}$ obje knjige, što nije karakteristično za njihove autore, donose se ekstenzivni citati iz dvaju Geertzovih eseja: Podroban opis: Prema interpretativnoj teoriji kulture (Thick Description: Toward an Interpretive Theory of Culture) i Religija kao kulturni sistem (Religion as a Cultural System). ${ }^{55}$ 
Lindbeck u uvodu svoje knjige jednostavno tvrdi da doktrine (doctrines) ne pružaju uobičajene pretpostavke o vlastitim vrstama i o tome što su one zapravo. ${ }^{56}$ Stoga nam je potreban nov i bolji način razumijevanja njihove priro-

Kao ilustrativni primjer grubog opisa, C. Geertz navodi primjer koji je također preuzeo od G. Rylea: tikovi, namigivanja, lažna namigivanja, parodije, probe parodija, a zatim donosi i vlastiti primjer podrobnog opisa: jednu malu dramu koja se odigrala u planinama centralnog Maroka 1912. Usp. ibid., str. 6-7. Michael Walzer je u knjizi Thick and Thin: Moral Argument at Home and Abroad (University of Notre Dame Press, Notre Dame 1994.) navedene pojmove primijenio na moralne argumente, a Avishai Margalit u knjizi The Ethics of Memory (Harvard University Press, Cambridge 2002.) na dva tipa ljudskih odnosa: u jednom (thick) riječ je o odnosu prema bliskim i dragim osobama, a u drugom (thin) o odnosu prema strancima.

38

C. Geertz, The Interpretation of Cultures, str. 28. 39 Ibid.

40

Ibid., str. 93. Usp. ibid., str. 216.

41

Ibid., str. 94.

42

Ibid., str. 216

43

W. Goodenough, nakon što je ustvrdio da kultura nije materijalni fenomen, da se ne sastoji od stvari, ljudi, ponašanja i emocija, poentira: $»$ Kultura] je organizacije svega toga. Ona je forma stvari koje ljudi imaju u umu, njihovi modeli zapažanja, povezivanja i interpretiranja.« Vidi: Ward Goodenough, »Cultural anthropology and linguistics«, u: Paul L. Garvin (ur.), Report of the Seventh Annual Round Table Meeting on Linguistics and Language Study, Georgetown University, Washington 1957., str. 167-177, str. 167.

44

C. Geertz, The Interpretation of Cultures, str. $12-13$.

45

Ibid.

46

Ibid., str. 142-170. C. Geertz razlikuje kulturu i društvenu strukturu. Kultura je »uređeni sustav značenja i simbola pomoću kojeg se odvijaju društvene interakcije, dok je društveni sustav obrazac same društvene interakcije«. Vidi: ibid., str. 144. Drugim riječima: »Kultura je osnovna struktura značenja pomoću koje ljudska bića interpretiraju svoje iskustvo i upravljaju svojim djelovanjem; društvena struktura je oblik koji poprima djelovanje, ona je stvarno postojeća mreža društvenih odnosa. Kultura i društvena struktura su, prema tome, različite apstrakcije istog fenomena.« Vidi: ibid., str. 145. C. Geertz nadalje tvrdi da su te dvije različite apstrakcije integrirane na vrlo različite načine. Društvena struktura je povezana na osnovi »kauzalno-funkcionalne integracije«, ona je artikulacija različitih dijelova koji su u interakciji i održavaju sustav. Kulturi je, usuprot, svojstvena logičkosmislena integracija, »jedinstvo stila, logički smisao, značenje i vrijednost«. To je neka vrsta koherentne jedinice, »kakvu nalazimo u Bachovoj fugi, dogmi Katoličke crkve ili teoriji relativnosti«. Vidi: ibid. Da su kulturalna i društvena oblast različite, iako međuovisne, te da svaka mora biti tumačena u njoj samoj isticali su W. Goodenough, C. Lévi-Strauss i D. Schneider. Usp. Roger M. Kessing, »Theories of Culture«, Annual Review of Anthropology 3 (1974), str. 73-97, str. 83, doi: https://doi. org/10.1146/annurev.an.03.100174.000445.

47

C. Geertz, Local Knowledge, str. 233.

48

Ibid.

49

Ibid., str. 233-234.

50

C. Geertz, The Interpretation of Cultures, str. 14. 51

Da je C. Geertz »podatan « za raznolike studije, jasno pokazuje zbornik Interpreting Clifford Geertz.

52

Naziv Yale School rabi se jer su temeljni autori postliberalne teološke tendencije vezani uz Divinity School Sveučilišta Yale, a sintagmom »narativna teologija « ističe se uvjerenje postliberalnih teologa da se kršćanska vjera ne zasniva na »univerzalnom razumu« ili »ljudskoj samosvijesti«, nego na »priči« (story), čije se pak tumačenje ne zasniva na nekakvoj argumentativnoj teoriji ili drugoj priči. Usp. Gerard Loughlin, Telling God's Story: Bible, Church and Narrative Theology, Cambridge University Press, Cambridge 1996., str. 33. Postliberalna teologija, napominje J. Webster, referira se na znatno šire teološko područje od tzv. Yale school - riječ je o setu projekata, a ne jedinstvenoj poziciji. Naziv je »postliberalna teologija« dobar jer ukazuje na zajednička svojstva različitih suvremenih teologa i različitih teoloških konteksta. J. Webster zajedničke osobine postliberalne teologije grupira oko tri točke: dok- 
de (nature) i uloge (function). To mu je, napominje, postalo jasno nakon što je bio dvadeset i pet godina uključen u ekumenske diskusije i predavao povijest i suvremeni položaj doktrina te je spoznao da mu nedostaju adekvatne kategorije za konceptualizaciju problema koji se pojavljuju. Problem nije ograničen samo doktrinama per se, nego obuhvaća i poimanje religije. Zapravo: teorije religije i teorije doktrine međuovisne su; nedostatci u jednom području, nedostatci su i u drugom području. Svi su standardni teološki pristupi bespomoćni. Poteškoće, međutim, ne mogu biti riješene jednostavnim odbacivanjem modernog razvoja i povratkom pred-liberalnoj ortodoksiji. ${ }^{57}$ Potreban nam je, stoga, treći put: postliberalni način tumačenja religija i religijskih doktrina. Teorija religije i religijskih doktrina koju nudi Lindbeck nisu ni specifično ekumenske, ni kršćanske, ni teološke, nego dolaze iz filozofijskih i socioloških pristupa - ali su, smatra Lindbeck, korisne i kršćanskoj religiji, i ekumenizmu, i teologiji. ${ }^{58}$ Drugim riječima, Lindbeck ističe da teorija religije $i$ doktrina ne može biti ekumenska ako nije izvanekumenski plauzibilna. Međutim, naglašavanje doktrinarne neutralnosti, ističe Lindbeck, ne uključuje teološku neutralnost. Sâm Lindbeck snažno je motiviran upravo kršćanskim jedinstvom, crkvom, »slavom Božjom «. ${ }^{59}$

Lindbeck je kao alternativu kognitivnom (doktrine funkcioniraju kao informativne propozicije i istinite izjave o objektivnim stvarnostima; riječ je o svojevrsnom izomorfizmu strukture spoznavanja i strukture spoznavanog), ${ }^{60}$ iskustveno-izražajnom (experiential-expressive) pristupu (doktrine se shvaćaju kao neinformativni i ne-diskurzivni simboli unutrašnjih osjećaja, stavova i egzistencijalnih orijentacija; ovaj pristup osvjetljava sličnost religijskog s estetskim djelovanjem i naročito je kongenijalan liberalnoj teologiji koja je nastala utjecajem kontinentalne teologije započete Schleiermacherom) ${ }^{61}$ te pristupu koji pokušava kombinirati spomenuta dva (kognitivno-propozicijski i ekspresivno-simbolički) ${ }^{62}$ ponudio kulturno-lingvistički (cultural-linguistic) pristup religijama. ${ }^{63}$ Pri takvom se pristupu naglasak stavlja na sličnost religija jezicima i njihovim korelativnim oblicima života, odnosno semiotički shvaćenim kulturama (idiomsko konstruiranje stvarnosti). To, nadalje, znači da je funkcija religijskih doktrina, za razliku od kognitivno-propozicijski i ekspresivno-simboličkih tumačenja, davanje autoritativnih pravila zajednice (communally authoritative rules), njezinih diskursa, stavova i djelovanja. Dakle, religijske su doktrine »regulativne« (regulative) ili »upravljačke« (rule) teorije. ${ }^{64}$ Uvid da crkvene doktrine nalikuju pravilima nije novum. Ideja regulae fidei poznata je već od ranog kršćanstva, a teolozi kasnijih razdoblja prepoznavali su operacionalnu logiku, odnosno regulativno pravilo religijskih doktrina. Oni su, drugim riječima, prepoznali da je djelomična zadaća doktrina preporučiti ili isključiti stanovitu domenu propozicijskih iskaza ili simbolizirajućih aktivnosti. Ipak, smatra Lindbeck, logika autoritativnih pravila zajednice (doktrine) otežava ili prevenira od onoga što treba biti afirmirano: kulturalno-lingvistički pristup. ${ }^{65}$ Prema takvom se pristupu religije tumače kao »sveobuhvatne interpretativne sheme« - uobičajeno »utjelovljene« u mitovima ili narativima te uvelike ritualizirane - koje strukturiraju ljudsko iskustvo i razumijevanje sebe i svijeta. ${ }^{66}$ Drugim riječima, religije funkcioniraju kao svojevrsni kantovski a priori, iako je u ovom slučaju a priori set stečenih vještina. Kao kultura ili jezik, religija je fenomen zajednice koji oblikuje subjektivitet pojedinca, a ne manifestacija subjektiviteta. Ona uključuje rječnik diskurzivnih i ne-diskurzivnih simbola zajedno s distinktivnom logikom ili gramatikom u pojmovima kojima taj rječnik može biti smisleno razmješten. Konačno, kao »jezična igra« (L. Wittgenstein) religija korelira s formama života i, kao i kultura, ima kognitivnu i biheviorističku dimenziju. Njezine 
doktrine, kozmologije, mitovi i etičke direktive integralno su povezane s ritualima, osjećajima koje oni evociraju, djelovanjima koje preporučuju, institucionalnim formama koje razvijaju. ${ }^{67}$

trine (manja kritičnost prema naslijeđenim doktrinarnim standardima), metode (uporaba deskripcijske metode) i kritike (postliberalni teolozi naširoko su kritizirani zbog isticanja važnosti doktrina). John Webster, »Theology after Liberalism?«, u: John Webster, George P. Schner (ur.), Theology After Liberalism, Blackwell Publishers Ltd, Oxford 2000., str. 52-61. A. Mcgrath ističe da je temeljna odrednica postliberalne teologije odbacivanje »totalizirajućeg« projekta moderne - bilo da je riječ o prosvjetiteljskom pozivanju na »univerzalni razum«, bilo da je riječ o liberalnom pozivanju na neposredno religiozno iskustvo zajedničko svim ljudima. Na mjesto takvih »pseudo-univerzalija«, postliberali stavljaju religijsku zajednicu i tradiciju posredovanu narativima. W. C. Placher istaknuo je sljedeće tri osnovne odrednice postliberalne teologije: 1) prvenstvo naracije kao interpretativne kategorije za tumačenje Biblije; 2) hermeneutičko prvenstvo svijeta koji je oblikovala biblijska naracija u odnosu na svijet ljudskog iskustva i 3) prvenstvo jezika u odnosu na iskustvo. Usp. Alister E. McGrath, »An Evangelical Evaluation of Postliberalism«, u: Timothy R. Phillips, Dennis L. Okholm (ur.), The Nature of Confession, InterVarsity Press 1996., str. 23-44, str. 23-24. G. Lindbeck također je u više navrata isticao da postliberalizam pripada formalnoj, a ne materijalnoj kategoriji, da je on prvenstveno istraživački projekt koji može obuhvatiti različite teološke tradicije. Usp. ibid., str. 13. Uz to, G. Lindbeck napominje da se ono što naziva »postliberalnom teologijom《 moglo nazvati i »postmodernom «, »postrevizionističkom《 ili »post-neo-ortodoksnom «, ali je naziv "postliberalna« izabrao jer je riječ o teologiji koja se pojavljuje nakon utemeljenja iskustveno-izražajnog pristupa, koji je obilježje liberalne metode. Usp. George Lindbeck, The Nature of Doctrine. Religion and Theology in a Postliberal Age, The Westminster Press, Philadephia 1984., bilj. 1, str. 135.

53

Riječ je o knjizi »koja je više od ikoje druge prepoznata kao klasični iskaz teološkog postliberalizma«. Vidi: J. Webster, G. P. Schner (ur.), Theology After Liberalism, str. 361. U uvodnom poglavlju (»Theory, Ecumenism, and Culture: The Proposal in Context«) svoje knjige G. Lindbeck navodi niz autora koji su utjecali na njegov kulturno-lingvistički pristup religijama. To su: M. Weber, E. Durkheim, L. Wittgenstein, P. Winch, P. Berger, N. Smart, W. Christian i, nedvojbeno najznačajniji, C. Geertz. Navedeni autori, ističe G. Lindbeck, nisu potaknuti samo suvremenim poteškoćama već i snažnom tradicijom čiji korijeni sežu od Kanta, koji je radikalnom kritikom metafizičkog i epistemološkog temelja ranije vladajućih kognitivno-propozicijskih gledišta omogućio njihovo pojavljivanje. Ipak, Kant nije zamijenio tumačenje religije koje je potkopao novim tumačenjem, smatra G. Lindbeck. Usp. G. Lindbeck, The Nature of Doctrine, str. 20-21.

54

Osim G. Lindbecka i (»kasnog«) H. Freija, postliberalnim teološkim tendencijama pripadaju i njihovi istaknutiji studenti: William Placher, Stanley Hauerwas i George Hunsinger. Usp. T. R. Phillips, D. L. Okholm (ur.), The Nature of Confession, str. 11. G. Lindbecku i H. Freiju, A. E. McGrath pridodaje Davida Kelseyja (The Uses of Scripture in Recent Theology, 1975.) i Paula Holmera (Grammar of Faith, 1978.). Usp. A. E. Mcgrath, »An Evangelical Evaluation of Postliberalism«, str. 23 .

55

G. Lindbeck u završnom poglavlju (»Toward a Postliberal Theology «) navodi citate sa str. 17, 21, 14 (G. Lindbeck krivo navodi broj str. 13, osim toga krivo citira: umjesto »interworked «, kako piše u Geertzovoj knjizi, G. Lindbeck piše »interlocked«), 10 i 26 Geertzove knjige The Interpretation of Cultures, Basic Books, New York 1973. (u kojoj se nalaze gore spomenuti eseji). Osim toga, pri oslikavanju religije kao sistema diskurzivnih i ne-diskurzivnih simbola koji povezuju motivaciju i djelovanje te pružaju konačnu legitimaciju za osnovne oblike misli, osjećaja i ponašanja karakterističnih za određenu zajednicu ili društvo, njegove članove, G. Lindbeck referira se na Interpretation of Cultures, str. 90. Usp. G. Lindbeck, The Nature of Doctrine, str. 62. H. Frei iz spomenute Geertzove knjige navodi citate sa str. 14, 1213 i 89-90. H. Frei na jednom drugom mjestu napominje da je C. Geertz svojim viđenjem etnografije, odnosno antropologije, bliži M. Weberu negoli E. Durkheimu. Usp. Hans W. Frei, »Theology and Interpretation of Narrative: Some Hermeneutical Considerations «, u: George Hunsinger, William C. Placher (ur.), Theology \& Narrative, Oxford University Press, New York, Oxford 1993., str. 94-116, str. 100. Dodajmo da H. Frei smatra da je sociologija M. Webera znatno kompleksnije teorijsko postignuće od sociologije E. Durkheima. Naime, prema H. Freiju, Weberova teorija nije zasnovana na općim i predvidljivim uzročnim shemama, ni na univerzalističkoj deskripciji bîti religije, nego ponajprije na intencionalnom djelovanju, opisivom razlogu koji ga vodi. Usp. ibid., str. 97-98.

56

G. Lindbeck (crkvenu) »doktrinu« opisuje kao komunalno autoritativno učenje koje zahtjeva vjeru i prakticiranje koje se smatra bitnim za identitet. Doktrina, bez obzira što 
Prema kulturno-lingvističkom pristupu, ljudsko iskustvo oblikovano je i konstituirano kulturnim i lingvističkim formama. Religija je ponajprije verbum externum koja uobličuje sebstvo i njegov svijet, a ne izraz ili tematizacija pre-egzistirajućeg sebstva ili pre-konceptualnog iskustva. Verbum internum (u klasičnom teološkom studiju izjednačena s djelovanjem Duha) također je iznimno važna, ali ona bi trebala biti shvaćena ne kao u iskustveno-izražajnom pristupu (zajedničko iskustvo različito artikulirano u različitim religijama), nego kao mogućnost da se čuje i prihvati stvarna religija, stvarni izvanjski svijet. ${ }^{68} \mathrm{Da}$ bi egzemplificirao kako kulturno-lingvistički pristup može prilagoditi i kombinirati distinktivne i često konkurirajuće naglaske kognitivnog i iskustveno-izražajnog pristupa, Lindbeck navodi Tillichovu iskustveno-izražajnu formulu: »religija je supstancija kulture, kultura je oblik religije«, što - napominje Lindbeck - znači da je religija u smislu krajnje zaokupljenosti (ultimate concern) zapravo vitalizirajući izvor svih značajnih kulturalnih dostignuća. ${ }^{69}$ Alternativa Tillichu, ističe Lindbeck, nije nijekanje, nego stanovito proširivanje, točnije »izokretanje« kompleksnijom formulom:

$» .$. religija je krajnja dimenzija kulture (zato što se odnosi na sve ono što se smatra najvažnijim) jer daje oblik i intenzitet iskustvenoj matrici iz koje proizlaze značajna kulturalna dostignuća. $\ll^{70}$

Osnovni »lik« ovoj formulaciji, prema Lindbecku, bliži je aristoteličkom hilemorfizmu, nego Schellingovu i Hegelovu idealizmu - koji su utjecali na Tillichovo razumijevanje. ${ }^{71} \mathrm{U}$ oba slučaja »forma « je neodvojiva od »materije«, ali u hilemorfičkom modelu »forma« ima prioritet (iskustvo egzistira samo kada je »uobličeno«), dok u idealističkom modelu prioritet ima »materija«, odnosno iskustvo duha (Geist) koje se »objektivira« kulturnim i religijskim formama. Iako je u jednom slučaju iskustvo derivacijsko, a u drugom primordijalno, u oba modela spoznata je moć oblikovanja religioznog iskustva kulturom. U kulturno-lingvističkom invertiranju izvanjske i unutarnje dimenzije religije (Tillichove iskustveno-izražajne formule) događa se svojevrsno približavanje kognitivističkoj teoriji za koju je izvanjsko (propozicijski iskazi) primarno. Međutim, za kulturno-lingvistički pristup sveobuhvatne sheme ili priče, koje nisu propozicijski iskazi, strukturiraju sve dimenzije življenja, one su medij u kojem se kreće, set umijeća koji se koristi pri oblikovanju života. Dok su, dakle, religijske tvrdnje često od iznimne važnosti (kao što je u kršćanstvu), one su ipak konceptualni rječnici i sintaksa unutrašnje logike koja determinira vrste tvrdnji koje stvara religija. Kognitivan aspekt, iako često važan, nije primaran. Biti religiozan - kao i biti kulturno ili lingvistički kompetentan - znači interiorizirati set umijeća (sveobuhvatne sheme ili priče) njihovim prakticiranjem. Primarno znanje nije ono $o$ religiji ni što religija uči, nego na koji način biti religiozan. ${ }^{72}$

Što se tiče religije i istine (istinitih tvrdnji), Lindbeck ističe da kulturno-lingvistički pristup, za razliku od iskustveno-izražajnog, priznaje mogućnost »istinitih izjava« (truth claims). Da bi pojasnio, prvo distingvira »intrasistematske« (intrasystematic) i »ontološke« (ontological) »istinite izjave«. Prve su istinite izjave koherencijske, druge korespondirajuće sa stvarnošću (prema epistemološkim realistima, prvotne propozicije [first-order propositions]). U prvom slučaju izjave su istinite kada su koherentne s relevantnim kontekstom (koji ne čine samo druge izjave nego i korelativne forme življenja). Pogrješka kognitivističkog pristupa, smatra Lindbeck, u tome je što ne uviđa razliku između kršćanskog sistema koji je oblikovan setom i znanstvenog sistema koji se sastoji od aksioma, definicija i korolara. Za epistemološke realiste intrasistematska istina ili laž fundamentalni su u smislu da su neophodni, iako ne i 
dovoljni, za drugu vrstu istine: ontološku korespodenciju. Drugim riječima, izjave ne mogu biti ontološki istinite osim da su intrasistematski istinite, ali intrasistematske istine su moguće bez da su ontološki istinite. Intrasistematski

može biti formalno izložena ili neformalno operativna, ukazuje na ono što sačinjava vjerno prianjanje uz zajednicu. Usp. G. Lindbeck, The Nature of Doctrine, str. 74. Inače, G. Lindbeck iz kulturno-lingvističke perspektive razvija tzv. upravljačku teoriju (rule theory): koja nije locirana u trajne i doktrinarno značajne aspekte propozicijskih iskaza religije ili unutrašnje iskustvo, nego u priču koju govori i gramatiku koja ukazuje na način kako je priča ispričana i uporabljena. Usp. ibid., str. 80. Drugim riječima, »doktrine« su svojevrsna gramatička pravila, a ne propozicijski iskazi ili simboli koji izražavaju unutarnje osjećaje. Usp. ibid., str. 84. Za Lindbeckovo razumijevanje izraza »doktrina«, koji je usko vezan uz pojmove »dogma« i »ispovijest« (credo), vidjeti također: George A. Lindbeck, »Creed and Confession«, u: Encyclopedia Britannica, Encyclopedia Britannica Inc., Chicago 1974., Macropedia 5, str. 243-246.

57

Poteškoće su uočene, napominje G. Lindbeck, zbog tvrdnji o nepromjenjivosti i promjenjivosti, kompatibilnosti i isključivosti, jedinstva i različitosti doktrina, što je, barem u jednom djelu, diskutirano pod rubrikom $»$ razvoj doktrine" (development of doctrine), koja je bila u upotrebi nakon djela An Essay on the Development of Christian Doctrine (1845.) Johna Henryja Newmana. Usp. G. Lindbeck, The Nature of Doctrine, str. 11

58

Ibid., str. 7.

59

Ibid., str. 10 .

60

Bernard Lonergan, Insight, Harper \& Row, New York, London 1978., str. 399. Pri takvom (kognitivističkom) pristupu religije se tumače na sličan način kao i u klasičnom studiju filozofija ili znanost (science). To je pristup karakterističan za tradicionalne ortodoksije, ali također u nekoj mjeri i za anglo-američki filozofijskoanalitički način tumačenja religija (kognitivno osmišljavanje religijskih iskaza). Usp. G. Lindbeck, The Nature of Doctrine, str. 16.

61

G. Lindbeck navodi i filozofijske poticaje iskustveno-izražajnog pristupa: idealizam, romantizam i fenomenološki egzistencijalizam. Usp. ibid., str. 63.

62

Najprominentniji autori »trećeg« pristupa su Karl Rahner i Bernard Lonergan. Iako smatra da je bolji od bilo kojega »jednodimenzionalnoga«, G. Lindbeck napominje da se i ovaj pristup može zapravo svrstati u jedan od dva: kognitivno-propozicijski i ekspresivno-simbolički. Usp. ibid., str. 16.

63

G. Lindbeck smatra da je u kognitivno-propozicijskom i ekspresivno-simboličkom pristupu nemoguće ostvariti »doktrinarno pomirenje« (doctrinal reconciliation): za propozicionaliste su doktrine uvijek istinite ako su jednom istinite, odnosno ako su lažne, uvijek su lažne; za predstavnike ekspresivno-simboličkog pristupa nije važno što se događa na razini simboličkih (uključujući doktrine) objektivizacija, nego ono što se događa u osjećajima, stavovima, egzistencijalnim orijentacijama, praksama. Dakle, religijsko značenje može varirati, dok doktrine ostaju iste i obrnuto, doktrine mogu varirati bez promjene značenja. Treći put, prema G. Lindbecku, pribjegava svojevrsnoj intelektualnoj gimnastici i nije uvjerljiv (siromašan je u kriteriju determinacije kada naglašava konzistentnost doktrinarnog razvoja s izvorima vjere). Usp. ibid., str 16-17. G. Lindbeck je u sljedećim radovima polemizirao s Rahnerovom teorijom: »Reform and Infallibility«, Cross Currents 11 (1961), str. 345-356; » velopment and Contemporary Protestant Theology«, u: Edward Schillebeeckx, Boniface Willems (ur.), Man as Man and Believer, Concilium 21, Paulist Press, New York 1967., str. 133-146. S Lonerganovom teorijom polemizirao je u: »Protestant Problems with Lonergan on the Development of Dogma«, u: Philip McShane (ur.), Foundations of Theology, Gill \& Macmillan, Dublin 1971., str. 115-124.

64

G. Lindbeck, The Nature of Doctrine, str. 18. 65 Ibid., str. 18-19.

66 Ibid., str. 32 .

67

Ibid., str. 33. Religijski simboli, ističe C. Geertz, onima koji su spremi prihvatiti ih pružaju kozmičku garanciju ne samo kad je riječ o njihovoj sposobnosti da shvate svijet nego $i$ kad je riječ o tome da shvaćajući ga preciziraju svoje osjećaje, definiraju svoje emocije, što im omogućava da svijet podnesu - mrzovoljno ili radosno, smrknuto ili lako. Usp. C. Geertz, The Interpretation of Cultures, str. 104.

68

G. Lindbeck, The Nature of Doctrine, str. 34. 69

P. Tillich je teologiju u bitnome sveo na teologiju kulture. Naime, za njega religija nije 
istinite izjave ontološki su lažne ako su dio sistema kojemu nedostaju koncepti ili kategorije da se referira na relevantnu stvarnost, ali su ontološki istinite ako su dio sistema koji je sâm kategorijalno istinit (adekvatan). Ontološke istine religijskih izjava, kao i intrasistematske, iako su u nekoj mjeri slične, razlikuju se od takvih izjava u drugim vrstama diskursa. Njihova korespodencija sa stvarnošću samo je funkcija njihove uloge u konstituiranju formi življenja, načina bivanja u svijetu, koji korespondira s konačnom stvarnošću (Ultimately Real). Srednjovjekovno skolastičko tumačenje istine (adaequatio mentis ad rem) može biti ocrtano, smatra Lindbeck, kao dio šireg slaganja sebe s Bogom (isto se može reći i za Austinovo shvaćanje performativne uporabe jezika): religijski iskazi zahtijevaju propozicijsku istinu ontološke korespondencije samo utoliko ukoliko su performanse, čini i djela, koja pomažu kreiranju takve korespondencije. To se, dakako, ne događa u nereligijskom performativnom govoru, gdje izjave ne mogu istodobno funkcionirati i kao performativne i kao propozicijske. Toma Akvinski ilustrativan je primjer za ono što Lindbeck želi reći. On, napominje Lindbeck, ističe da iako u izjavama o Bogu ljudski način označavanja (modus significandi) ne korespondira sa samim božanskim bićem, označeno (significatum) ipak korespondira (usp. Summa theologiae I. 13. 3; Contra genitles I. 30). Primjerice, kada kažemo da je Bog dobar, ne tvrdimo da je ijedan naš koncept dobrote (modi significandi) primjenjiv na božansko, nego da postoji koncept dobrote nama nedostupan (Božje razumijevanje njegove dobrote). Ono što, dakle, tvrdimo jest da je iskaz »Bog je dobar « smislen i istinit, ali bez potpunog znanja o značenju tog iskaza. Međutim, iako postoji svojevrsni značenjski vakuum, significata se može afirmirati - tvrdi Lindbeck. Može se tvrditi da iskaz »Bog je dobar.« referira, odnosno korespondira sa stvarnošću iako se ne može specificirati modi significandi. Naime, riječ je o performativnoj funkciji religijskog iskaza: unatoč značenjskom vakuumu, iskaz »Bog je dobar« važan je jer autorizira priču o stvaranju, providnosti, otkupljenju kao dobrim Božjim djelima - što oblikuje vjernikove misli i djela. Vjernik, dakle, treba djelovati kao što je Bog bio dobar prema nama (quoad nos) i to na način kako je to prikazano u kanonskom tekstu (Biblija), uključujući i prihvaćanje tvrdnje da je Bog dobar u samome sebi (in se), iako tâ tvrdnja nadilazi mogućnosti ljudskog spoznavanja. ${ }^{73}$ Iz kognitivističke perspektive moglo bi se reći da je propozicijska supstancija (pr. creatio ex nihilo) nepromjenjiva, dok je konceptualna forma promjenjiva. No svaki pokušaj izoliranja »supstancije« (significatum) - uključujući i creatio ex nihilo - od modi significandi osuđen je na neuspjeh, tvrdi Lindbeck. ${ }^{74}$ Tvrdnja da Bog stvara ex nihilo treba služiti kao vodič kako vjernik treba govoriti i djelovati, a imali li ta tvrdnja propozicijsku snagu ovisi o »svakodnevnom jezičnom « kontekstu u kojem je ona izgovorena. ${ }^{75}$

Dakle, razumijevanje, ističe Lindbeck, nije locirano izvan semiotičkog sustava, nego je imanentno, konstituirano specifičnim jezikom. Stoga i odgovarajuće tumačenje riječi Bog ovisi o tome kako tâ riječ funkcionira unutar određene religije. Prema kulturno-lingvističkom pristupu značenje je imanentno, konstituirano uporabom specifičnog jezika, stoga je teološka deskripcija »intrasemiotička« (intrasemiotic) ili »intratekstualna« (intratextual). ${ }^{76}$ Sa stanovišta sveobuhvatnosti i kompleksnosti religije zahtijevaju, ističe Lindbeck, ono što Geertz, posuđujući termin od Gilberta Rylea, naziva thick description. Samo, thick description, napominje Lindbeck, ne smije biti poistovjećen s Baconovim empirizmom. On je puni opseg interpretativnog medija koji treba biti izložen i stoga je taj domet (opseg) u slučaju religije potencijalno sveobuhvatan. ${ }^{77}$ 
V.

Frei u svojoj knjizi Types of Christian Theology navodi dva osnovna, vrlo različita, ali zapravo ne nužno i međusobno isključiva, sagledavanja kršćanske teologije:

1) Teologija je primjer općeg ili generičkog tipa te se stoga mora podvesti pod opće kriterije razumljivosti, koherencije $\mathrm{i}$ istine pod koje se svode sve druge akademske discipline. Drugim riječima, njezino pravo da zadobije mjesto u sveučilišnom kurikulu ovisi o njezinoj egzemplifikaciji kriterija koje je postavila formalna filozofijska Wissenschaftslehre.

2) Teologija je aspekt kršćanstva i stoga djelomično ili u cijelosti definirana odnosom prema kulturnom ili semiotičkom sistemu koji konstituira religiju. Kršćanska je teologija ponajprije vezana uz iskaze prvog reda (firstorder statements) ili proklamacije koje se odnose na kršćansku praksu i vjerovanje. Kršćanska zajednica procjenjuje vlastiti jezik i djelovanje normama koje su norme sâme zajednice. Takvo procjenjivanje ima dva aspekta: deskriptivni (nastojanje da se artikulira »gramatika« ili »unutrašnja

neka posebna funkcija čovjekova duhovnoga života, nego dubinska dimenzija u svim funkcijama. Ona je svugdje »kod kuće«: u ćudoređu, u spoznaji, u umjetnosti, u osjećaju. Religija je osnova, temelj i dubina duhovnog života. Ona je krajnja zaokupljenost (ultimate concern). Usp. Paul Tillich, Theology of Culture, Oxford University Press 1959., str. 8. Ono neuvjetovano, kojega smo izravno i bez naknadnog izvođenja svjesni, može se uočiti, smatra P. Tillich, u svijetu kulture - koja je za Tillicha slika, zakon, politički pokret i dr. Dakle, Tillich smatra da je kultura ukupnost oblika u kojim se iskazuje religija, koja je smisaona supstancija kulture. Ukratko: religija je supstancija kulture, kultura je oblik religije. Svaki religijski čin - bilo da je riječ o kakvoj organiziranoj religiji ili najintimnijem titraju duše - kulturalno je oblikovan. Glasovita Tillichova tvrdnja da je religija supstancija kulture, a kultura oblik religije nalazi se u više njegovih radova: »Church and Culture«, $\mathrm{u}$ : The Interpretation of History, New York, London 1936., str. 235; »The 'Philosophy of Religion' ", u: James L. Adams (ur.), What is Religion, New York 1969., str. 73; »Author's Introduction« i »Religion and Secular Culture«, u: Protestant Era, Chicago 1957., str. xiii, 57; »The Spiritual Community and the Unity of Religion, Culture and Morality «, u: Systematic Theology, III, The University of Chicago Press, Chicago, London 1963., str. 158. Usp. Dubravko Arbanas, Koncept 'vrhunske brige' u mišljenju Paula Tillicha, doktorska disertacija, Filozofski fakultet Družbe Isusove, Zagreb 2014., bilj. 170, str. 40, bilj. 204 , str. 48. Iz naslova disertacije očito je da D. Arbanas Tillichovu sržnu sintagmu ultimate concern prevodi kao vrhunska briga.

70

G. Lindbeck, The Nature of Doctrine, str. 34 .
71

Ibid.

72

Ibid., str. 34-35.

73

Ibid., str. 64-67.

74

Ibid., bilj. 22, str. 90 .

75

Ibid.

76

Na Lindbeckov koncept »intratekstualnosti« utjecalo je obnavljanje interesa za »literalno značenje« (sensus literalis) biblijskih tekstova H. Freija. G. Lindbeck pojašnjava da je o intratekstualnosti mislio bez svijesti o teoriji dekonstrukcije. Ali, zajedno s pripadnicima potonje teorije ne stavlja naglasak na tekst kao samostalan estetski objekt ili »verbalnu ikonu«. Za G. Lindbecka tekst je »medij interpretacije« i u tom smislu dijeli dekonstrukcijsko isticanje teksta kao konstituirajućeg svijeta unutar kojega sve može biti ili je protumačeno. No za razliku od dekonstrukcionista, G. Lindbeck smatra da postoji »privilegirani idiom«, odnosno tekst prema kojemu su svi tekstovi međusobno interpretirajući. Stoga i koristi naziv intratekstualnost, a ne intertekstualnost. Usp. G. Lindbeck, The Nature of Doctrine, str. 136. H. Frei se pri tumačenju sensus literalis također pozvao na shvaćanje da »svijet« treba biti razumljen $u$ modelu »teksta«, pri čemu H. Frei ističe doprinos Jacquesa Derridaa. Vidi: Hans W. Frei, Types of Christian Theology, prir. George Hunsinger, William C. Placher, Yale University Press, New Haven 1992., str. 17.

77

G. Lindbeck, The Nature of Doctrine, str. 115 
logika« kršćanskih iskaza prvoga reda) i kritički (nastojanje da se prosuđuje svaka artikulacija kršćanskog jezika s obzirom na uspjeh ili neuspjeh u prihvaćanju spoznatih normi ili normi koje određuju vjernikovo prihvaćanje jezika).

Što se tiče prvog gledišta, srodna disciplina teologije je filozofija (ne samo kao transcendentalna analiza, nego i kao pozitivna procedura $\mathrm{u}$ epistemologiji). Srodna disciplina drugom gledištu (deskriptivnom i kritičkom aspektu procjenjivanja) interpretativna je društvena znanost, posebice antropologija i sociologija. Frei, nadalje, nudi tipologizaciju pet različitih stavova s obzirom na navedena dva gledišta (teologija je filozofska disciplina i kao takva ne ovisi o samodeskripciji unutar religijske zajednice; teologija je podređena filozofiji, ali istodobno se traži korelacija specifično kršćanskog s općim kulturnim značenjskim strukturama kao što su prirodne znanosti; teologija je korelativna formalnom, univerzalnom i transcendentnom kriteriju važećeg mišljenja; teologija je nesistematična kombinacija normirane kršćanske samodeskripcije i metode zasnovane na općoj teoriji; teologija je isključivo stvar kršćanske samodeskripcije) i to u prvom redu općenito, a potom i na način kako se svaki od pet tipova odnosi prema sensus literalis (s posebnom pozornošću na figuru Isusa). ${ }^{78}$ Za prvi su tip ilustrativan primjer Kant i Gordon Kaufman, za drugi, doduše svaki na svoj način, liberalni teolozi Rudolf Bultmann, Wolfhart Pannenberg i David Tracy te Karl Rahner i Carl Henry, za treći Friedrich Schleiermacher i Paul Tillich, za četvrti tip Jonathan Edwards, John Henry Newman i Karl Barth te za peti (nema formalnog, od konteksta neovisnog seta transcendentalnih načela koji upravljaju nekakvom unutrašnjom logikom; kršćanska teologija je »gramatika vjere « [grammar of the faith], procedura samodeskripcije za koju nema izvanjskih korelata) Dewi Zephaniah Philiphs. ${ }^{79}$

Religiozne teorije nakon Kanta, ističe Frei, usredotočile su se na vjeru kao distinktivno i samosvjesno stajalište nesvodivo na bilo što drugo. Vjera je tako postala analogon načinu na koji za Kanta struktura razuma kvalificira kontakt transcendentalnog ega s objektima opipljivog svijeta - koji nisu stvari po sebi (Ding an sich), nego fenomeni ljudske svijesti. Tako je opće mjesto devetnaestostoljetne protestantske teologije postalo uvjerenje da mi spoznajemo Boga samo u religijskom odnosu s njim. Više od bilo koga drugoga to je stajalište oblikovao u teološki sistem Schleiermacher, za kojega je svaka teološka doktrina normativna samo utoliko, ukoliko je »obuhvaćena« izjavama vjere (Glaubensaussage), odnosno religioznim odnosom s Bogom. ${ }^{80}$

Usuprot takvih tendencija, središte Freijeva teološkog projekta novo je shvaćanje klasičnog egzegetskog načela: sensus literalis, ${ }^{81}$ stoga je za njega temeljno pitanje koji je tip teologije najprijemčiviji za literalno značenje Biblije. To je, dakako, onaj tip teologije kod kojega prevladava samointerpretacija i svojevrsna »hermeneutika obnavljanja smisla« (P. Ricœur). Literalni smisao, ističe Frei, ne proizlazi iz imanentnog tekstualnog oblika, nego iz plodne uporabe. ${ }^{82}$ On nije opće hermeneutičko pravilo, nego primjer specifičnog slučaja koji pripada kontekstu socio-lingvističke zajednice. ${ }^{83}$ Drugim riječima, značenje Evanđelja nije dano odvojeno od zajednice koja ga upotrebljava, stoga je zadaća hermeneutike deskriptivna. ${ }^{84}$ Narativni referent nije ni objektivna stvarnost (koja, prema Freiju, može biti povijesna ili metafizička) ni »transcendentalno utemeljeno razumijevanje «. ${ }^{85}$ Prihvaćanjem da tekst »stoji sam za sebe u nadležnosti očigledne samorazumljivosti«, udaljen od svake faktične reference, autorske intencije ili čitateljeve recepcije Frei je vrlo bli- 
zak tendencijama Nove kritike (New Criticism) - čijem sirenskom zovu nije odolio ni Geertz. ${ }^{86}$

78

H. Frei kršćanski identitet ne locira u »povijesnog Isusa«, nego u narativno prikazivanje Isusova života, smrti i uskrsnuća. H. Frei ističe da su mnoge evanđeoske epizode samo ilustrativne anegdote (illustrative anecdotes) dok je uskrsnuće Isusa iz Nazareta središnja narativna sekvenca evanđelja. Po događaju uskrsnuća manifestira se tko je Isus, njegov istinski identitet. Do istinskog Isusova identiteta, prema H. Freiju, u svojim nastojanjima nisu mogli doći ni »stari«, ni »novi« tragatelji za »povijesnim Isusom«, ni njihovi oponenti jer su imali krivo razumijevanje identiteta (samostojeće ja, »duh u stroju« [G. Ryle]) Za razliku od »metafizičkog« koncepta identiteta, H. Frei smatra da se identitet otkriva $\mathrm{u}$ namjera-djelatnom opisu identiteta (intention-action description of the self's identity), odnosno u opisu javnog namjernog djelovanja (description of intention-with-action-inpublic). Tko je neka osoba otkriva se ponajprije u razvoju konzistentnih namjera »utjelovljenih« $\mathrm{u}$ društvenom djelovanju. Kada, dakle, namjera-djelovanje (intention-action) kombinacija nije samo periferna osobi, nego je od središnje važnosti, tada - ističe H. Frei - osoba zadobiva identitet. Osobni identitet je konstituiran (ne samo ilustriran) namjerama koje postaju djelovanje. Usp. Hans W. Frei, » Theological Reflections on the Accounts of Jesus' Death and Resurrection«, u: G. Hunsinger, W. C. Placher, Theology \& Narrative, str. 45-93. H. Frei ocrtanom koncepcijom identiteta suprotstavlja se tzv. novom traganju (new quest) za povijesnim Isusom čij su reprezentanti G. Ebeling, E. Fuchs i R. Bultmann. Pri »novom« razumijevanju identiteta, H. Frei oslonio se na Ryleov koncept identiteta kao onoga koji je zasnovan na govoru i djelovanju osobe. Samo, H. Frei čuvao se od moguće optužbe za kriptobiheviorizam koji niječe bilo kakvu »unutrašnjost«, stoga je tvrdio da osoba ima namjere (intentions) kao i djelovanja (actions) - što, ističe H. Frei, nije lako objasniti. Usp. Hans W. Frei, The Identity of Jesus Christ: The Hermeneutical Basis of Dogmatic Theology, Fortress Press, Philadephia 1975., str. 43.

79

Hans W. Frei, Types of Christian Theology, Yale University Press, New Haven, London 1992., str. 1-7.

80

Hans W. Frei, The Eclipse of Biblical Narrative, Yale University Press, New Haven, London 1974., str. 283-284.

81

Budući da biblijska egzegeza konstituira teološku znanost u sâmom njezinom načelu, sas- vim je razumljivo da Akvinčev članak o sacra theologiae u svojoj Sumi završava objašnjavanjem egzegetskog načela. Riječ je o topičkom mjestu srednjovjekovne kršćanske kulture, koje je Aleksandar iz Danske na kraju prvog poglavlja (De introductoriis scientiae theologicae) svoga djela Rotulus pugillaris (oko 1260.) sumirao sljedećim dvostihom: Littera gesta docet, quid credas allegoria, / moralis quid agas, quid speras anagogia. Dakle, najelementarniji smisao (sensus literalis) u kojem Biblija može biti shvaćena povijesni je ili doslovni smisao. Na njemu se temelje drugi smislovi, koje Akvinski okuplja pod jedinstvenim duhovnim smislom (sensus spiritualis): »Illa vero significatio qua res significatae per voces, iterum res alias significant, dicitur sensus spiritualis, qui super litteralem fundatur et eum supponit.« (Summa Theologiae I q. 1, a. 10 c). Doslovni smisao izjednačuje se sa sâmim događajima - u značenju Svete povijesti. To znači da likovi i činjenice Svete povijesti posjeduju vrijednost znaka te pored svoje povijesne istine i zbilje posjeduju simboličku zbilju. Bog je uredio događaje Svete povijesti tako da oni budu označitelji: »Deus adhibet ed significationem aliquorum ipsum cursum rerum suae providentiae subiectarum.«(Quodl., VII, 6, 16 c).

82

Hans W. Frei, » The 'Literal Reading' of Biblical in the Christian Tradition: Does It Stretch or Will It Break?«, u: G. Hunsinger, W. C. Placher (ur.), Theology \& Narrative, str. 120.

83

Ibid., str. 144-146.

84

Riječ je o tzv. kasnom H. Freiju koji je pod utjecajem Lindbeckova pragmatizma odbacio ranije pokušaje povezivanja literalnog smisla s formalnim tekstualnim svojstvom te je literalni smisao počeo tumačiti kao ono što proizlazi iz tradicionalne ekleziološke uporabe Biblije.

85

H. W. Frei, »Theology and the Interpretation of Narrative«, u: G. Hunsinger, W. C. Placher (ur.), Theology \& Narrative, str. 107.

86

Clifford Geertz, Works and Lives. The Anthropologist as Author, Stanford University Press, Stanford 1988., str. 6. S. Hauerwas napominje da se sâm tekst pojavljuje kao posljedica interpretativne uporabe $\mathrm{i}$ da $\gg$ stoga ne možemo pitati kako trebamo interpretirati tekst jer tada pretpostavljamo da tekst postoji prije interpretativnih strategija. Moramo prihvatiti da interpretativne strategije već djeluju pri 


\section{VI.}

Da se vratim Sloterdijku i njegovu apelu. Sloterdijk je u nastojanju da zasnuje jednu opću znanost o kulturi, koja bi bila moderator ekumene, sklopio svojevrsno »savezništvo《 s »religijom《 - točnije s onim što smatra da je religija: psihosemantička institucija koje služi preradi smetnji u integritet. ${ }^{87}$ Međutim, s druge strane, religija (odnosno teologija, još preciznije: reformacijska postliberalna teologija) »savezništvo« nije pronašla u Sloterdijkovoj egzercicijskoj teoriji zasnovanoj na antropotehnikama, nego interpretativnoj znanosti o kulturi. Točnije, u njezinu najprominentnijem zagovaratelju: Geertzu. Sâma reformacijska teologija reformirala se, dakle, upravo onom znanošću koja je nastajala u emancipacijskom pokretu od teologije (i filozofije) i koja se smatrala »znanošću reformatora«. Štoviše, i ovaj puta (kao što je bio slučaj i s filozofijom), znanost koja se emancipirala od teologije ubrzo je u teološkom studiju postala ancilla theologiae. Ali - i ovaj puta sluškinja je pokušala zagospodariti. Da prizovem u sjećanje Kanta - interpretativna znanost o kulturi stavila je religiju unutar granica sensus communis, koji za Geertza nije bloßen Vernunft, nego kulturalni sustav. ${ }^{88}$ Dakako, sluškinja je i poslužila (naročito u ekumenskom i intereligijskom dijalogu), pri čemu je donijela stanovite nevolje. Naime, iako postoji svojevrstan postliberalni konsenzus o primarnosti kulturalno-lingvističkog karaktera religija (što ne znači da se time nadilaze duboka neslaganja između progresivista i konzervativaca, feminista i antifeminista, katolika i protestanata) i okret prema razmatranju onog konceptualnog i gramatikalnog, i dalje ostaju dvojbe gdje se nalazi "prava« gramatika ili tko je kompetentan govornik religijskog jezika. ${ }^{89}$ Osim toga, Lindbeck polazi od jednostavne činjenice da je jezik, odnosno simbolički ustav dân. Ali - od kuda oni (jezik i simbolički sustav) dolaze, ostaje nepropitano. Postliberalna teologija zanemarila je zapravo jedan od središnjih teoloških pojmova: objavu.

Za razliku od liberalnih teoloških tendencija prema svojevrsnom ekleziološkom doketizmu, postliberalna teologija je u prvi plan stavila društveni organizam: Crkvu. Upravo stoga - jer ima potencijal »utjelovljenja« - postliberalna teologija ima i reformski potencijal koji nedostaje znanosti o kulturi, pa čak i kulturnim studijama, čija je ambicija razviti načine teoretiziranja odnosa kulture i moći što ih onda mogu rabiti društveni posrednici (ženski pokret, postkolonijalne borbe, pokret za oslobođenje crnaca i sl.) da bi prouzročili promjene u djelovanju tih odnosa. ${ }^{90}$ Crkva, ističu postliberalni teolozi, nema nekakvu kršćansku kulturu - Crkva jest kultura! Crkva, ističe Stanley Hauerwas, nema socijalnu etiku - ona jest socijalna etika. ${ }^{91}$ Crkva je stoga svojevrsna subverzivna zajednica, »antiinstitucionalna institucija«, agonistička »kultura u dijaspori«. ${ }^{92}$ Jezik Crkve može se naučiti »ulaskom« u zajednicu, što ukazuje

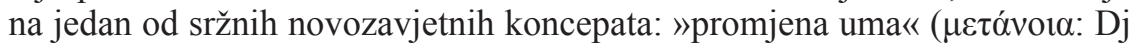
2,37; usp. Mt 3,2; 4,17; Mk 1,4; 1,15; Lk 3,3; 5,32). Tâ promjena nije platonički okret duše od mnijenja i postojanja $\mathrm{k}$ mišljenju i bitku (Resp. 515c4-7, $516 c 6),{ }^{93}$ nego nešto slično (samo slično!) Kantovu shvaćanju »okreta« od načela ljubavi prema sebi k moralnom zakonu, prijelaz na maksimu »njezine svetosti«, ulazak u »etičku zajednicu« ${ }^{94}$ To je ujedno, prema reformacijskoj teološkoj tradiciji, središnja i ključna reformacija, izvorište svakovrsnih promjena. Dakle, da bi se dogodila reforma - da se sada poslužim Rilkeovim stihom kojim se poslužio i Sloterdijk - čovjek »svoj život promijeniti mora« i to tako da prihvati nov sustav simbola, odnosno »privilegirani idiom « (G. Lindbeck). Isticanjem »privilegiranog idioma« postliberalna teologija udaljila se od interpretativne znanosti o kulturi.

Geertzovo mišljenje da Parsonsova teorija kulture (Talcott Parsons je razvio pojam kulture kao sistema simbola pomoću kojeg čovjek pridaje značenje 
vlastitom iskustvu), na odgovarajući način ispravljena, treba postati jedno od najmoćnijih intelektualnih oruđa u borbi protiv ideologija, zvuči izazovno. ${ }^{95}$ Međutim, problem koji je sâm uočio (mišljenje koje ističe postojanje »shema« koje utiskuju oblik izvanjskom procesu, olako prelazi preko onoga što se pojavilo kao glavni teorijski problem: kako konceptualizirati dijalektiku između kristalizacije takvih izravnih »obrazaca značenja « i konkretnog tijeka društvenog života, između kulturalnih obrazaca i društvenih procesa), mislim, ostaje neodgovoreno ili barem nedostatno odgovoreno. Pozivanje na »najvažniji trend recentne misli«: ono što je Kenneth Burke nazvao »simboličko djelovanje« (symbolic action) ${ }^{96}$ i »ekstrinzičnu teoriju mišljenja« (extrinsic theory of thought $)^{97} \mathrm{u}$ članku »Ideologija kao kulturalni sistem « (»Ideology As a Cultural System «) - u kojemu se kritički osvrće (jer ne propituju dovoljno ozbiljno ideologije kao sisteme uzajamno djelujućih simbola, odnosno uzajamno djelujućih značenja) na »teoriju napetosti« (strain theory) i »teoriju interesa (interest theory) - također mi se čini nedovoljno objašnjeno, iako u nekoj mjeri smjerodavno (isticanje trodimenzionalnosti - psihičke, društvene i kulturne - pri nastajanju ideologije). Isticanje složenosti mnoštva referenci-

oblikovanju našeg čitanja i shvaćanja što je tekst«. Vidi: Stanley Hauerwas, Unleashing the Scripture: Freeing the Biblie From Captivity to America, Abingdon Press, Nashville 1993., str. 20

87

Usp. P. Sloterdijk, Svoj život promijeniti moraš i Božja revnost.

88

Prema C. Geertz, sensus communis, odnosno »zdrav razum« nešto je sasvim drugačije od onoga što je filozofijska tradicija nazivala sensus communis - i to ne samo u smislu teorijske moći suđenja (svojevrsna mehanika ljudskog mišljenja koja nadilazi vremena, mjesta i kulture) nego i u smislu osjeta za zajedničko dobro. Sensus communis, prema C. Geertzu, kulturni je sustav, čiji je »stvoreni poredak« moguće empirijski otkriti i pojmovno formulirati. Usp. C. Geertz, Local Knowledge, str. 73-94.

89

G. Lindbeck smatra da opći okvir čini mogućim, iako ne garantira, nadilaženje relativnog podudaranja i različitih pozicija pravim argumentima. Naime, postliberalna teologija polarizaciju između propozicijskog naglašavanja nepromjenjivih istina $i$ liberalnog naglašavanja da su promjene i pluralnost $u$ religijskim ekspresijama nužne za razumljivost, vjernost i primjenjivost pokušava nadići razlikovanjem trajne doktrinarne gramatike i varijabilnog teološkog rječnika. Takav pristup, dakako, za druge perspektive nije onaj koji je spojio najbolje iz oba pristupa, nego najgori mogući pristup. Usp. G. Lindbeck, The Nature of Doctrine, str. 113.

90

Tony Bennett, Kultura: znanost reformatora, prevela Andrina Pavlinić, Golden marketing - Tehnička knjiga, Zagreb 2005., str. 45.
91

Stanley Hauerwas, In Good Company. The Church as Polis, University of Notre Dame Press, Notre Dame 1995., str. 22.

92

Rodney Clapp, A Peculiar People: The Church as Culture in a Post-Christian Society, InterVarsity Press 1996., str. 116. R. Clapp ističe se da je Crkva kultura u smislu »označavajućeg sustava« (R. Williams). Usp. ibid., str. 173174. Usp. Raymond Williams, The Sociology of Culture, University of Chicago Press, Chicago 1981., str. 12, 27, 207-210.

93

Petar Šegedin, Pojam uma u Platona, Matica hrvatska, Zagreb 2012., str. 311.

94

Kant ističe da za razliku od »juridičke« zajednice - u kojoj su zakoni usmjereni na vidljivu legalnost djelovanja, a ne na (unutarnju) moralnost - vrhovni zakonodavac »etičke« zajednice može biti samo netko u pogledu kojega se sve istinske dužnosti ujedno moraju predočavati kao njegove zapovijedi i koji ujedno mora biti poznavalac srcâ koji prozire i najdublju nutrinu svačijih nastrojenosti da bi dopustio da svakome pripadne onoliko koliko vrijede njegova djela. Takav vrhovni zakonodavac je »pojam Boga kao moralnog vladara svijeta«. Usp. Immanuel Kant, Religija unutar granica pukog uma, preveo Kiril Miladinov, Naklada Breza, Zagreb 2012., str. 48, 94-95.

95

Usp. C. Geertz, The Interpretation of Cultures, str. 249-254.

96

Ibid., str. 208.

97

Ibid., str. 215. 
jalnih veza između »semantičke strukture figura « i društvene stvarnosti koje se ne odvija »u glavi«, nego u javnosti, doima se kao »grub opis« (thin description). Štoviše, čini se eklektično (poziva se na niz autora: pr. W. Percy, G. Ryle, S. Langer) ${ }^{98}$ Konačno, interpretativna znanost o kulturi, ostavila nas je i pred sljedećim pitanjem: ako je znanost o kulturi interpretativna disciplina koja traga za značenjem, u ime kojeg autoriteta ona onda nudi interpretaciju? ${ }^{99}$ Nije li, naime, znanost o kulturi, barem u njezinim počecima, nerijetko bila sredstvo u rukama kolonizatora globalne ekumene? Nije li Tylorov pristup eurocentričan i apsolutistički? Jer mu je misaono blizak, Geertzov odgovor mogao bi biti sličan Rortyjevu odgovoru na kritike da njegova teorija ima problematičan status: takve su kritike promašene jer promašuju pragmatičan karakter na koji se Rortyjeva koncepcija zapravo poziva i iz čije perspektive pokušava djelovati. ${ }^{100}$ Geertz se ne poziva na pragmatičan karakter svoje teorije kulture, ali, mislim, upravo iz takve perspektive pokušava djelovati. U tom smislu interpretativna znanost o kulturi kao i postliberalne teološke tendencije čine se korisnima jer u kulturi »bez univerzalnih standarda« - ističe

98

P. Ricœur ističe da C. Geertz od K. Burkea preuzima samo termin, a ne pojam »simboličko djelovanje«. Naime, u Burkeovoj knjizi na koju se poziva (Philosophy of Symbolic Form: Studies in Symbolic Action, 1941.) »simboličko djelovanje «, ističe P. Ricœur, ima drugačije značenje od onoga koje sâm C. Geertz nudi. K. Burke smatra da je jezik, u stvari, »simboličko djelovanje«, dok C. Geertz tvrdi da je djelovanje simboličko, baš kao i jezik. Pojam »ekstrinzičnog simbola«, nastavlja P. Ricœur, također je »sumnjiv«. Naime, C. Geertz nastoji pokazati da djelovanjem upravljaju simboli »iznutra«. Vidi: Pol Riker [Paul Ricœur], »Gerc«, preveo Aleksandar Bošković, Kultura 118/119 (2007), str. 21.

99

George Marcus, Michael M. J. Fischer (ur.), Anthropology as Cultural Critique: An Experimental Moment in the Human Sciences, University of Chicago Press, Chicago, London 1999., str. 3. Tvrdnja da »interpretacija počinje od postulata da mreže značenja konstituiraju ljudsku egzistenciju« (Paul Rabinow, William Sullivan, »The Interpreting Turn: Emergence of an Approach«, u: Paul Rabinow, William Sullivan (ur.), Interpretive Social Science, University of California Press, Berkeley 1979., str. 1-30, str. 5), prema R. Rortyju, primjer je kako dobra tendencija društvenih znanosti - da se od galilejevske (neutralan rječnik znanosti koji odgovara prirodi) pretvori u »hermeneutičku« (rječnici služe tako što pomažu pri predviđanju i rješavanju društvenih problema) - može otići »predaleko« ako počne povlačiti načelne distinkcije između čovjeka i prirode, smatrajući da ontološka razlika diktira i metodološku. R. Rorty smatra da treba dokinutu razliku između objašnjenja i razumijevanja, razliku između dviju metoda (jedne za razumijevanje čovjeka, a druge za razumijevanje prirode). Biti »interpretati- van« ili »hermeneutičan«, prema R. Rortyju, ne znači imati nekakvu znanstvenu metodu, nego tragati za rječnikom koji bi mogao biti od pomoći. Kada se, nastavlja R. Rorty, pojavio Galileo s matematiziranim rječnikom, uspješno je okončao istraživanje koje je bilo hermeneutičko. Isto je i s Darwinom. Nema bitne razlike između onoga što su uradili oni i onoga što rade biblijski egzegeti, književni kritičari ili povjesničari kulture. Vidi: Richard Rorty, Consequences of Pragmatism, University of Minnesota Press, Minneapolis 1982., str. 198-199. »Opisivanjem svijeta« (description of the world) ne upravlja neki kriterij (svijet sam) izvan jezičnih igara, nego jezične igre kao cjelina. To - da nam svijet sam ne kazuje kojim jezikom trebamo govoriti - ne znači da je izbor vokabulara u potpunosti arbitraran. Riječ je istodobno o činu volje i rezultatu rasprave. Riječ je o postepenom gubitku navike upotrebljavanja jednog vokabulara i stjecanje navike upotrebljavanja drugih vokabulara. Usp. Richard Rorty, Contingency, Irony, and Solidarity, Cambridge University Press, Cambridge 1989., str. 5-6.

100

Koliko je R. Rorty misaono blizak C. Geertzu (dakako, uz neke razlike; usp. Richard Rorty, »On Ethnocentrism: A Reply to Clifford Geertz«, Michigan Quarterly Review 25 (1986), str. 525-534), ilustrativno pokazuje Rortyjeva misao da filozofija ne treba pronalaziti prirodna polazišta nezavisna od kulturnih tradicija, nego sve što treba jest uspoređivanje i kontrastiranje kulturnih tradicija. Usp. R. Rorty, Consequences of Pragmatism, str. xxxvii. I obrnuto, C. Geertz rortijevski piše »da se ne držimo onoga što je nekada davalo dovoljno dobre rezultate i dovelo nas do onoga gdje smo sad, a trenutačno ne funkcionira $\mathrm{i}$ dovodi nas u pat poziciju«. Vidi: Clifford Geertz, Available Light. Anthropological Reflections on Philosophical Topics, Princeton 
Zygmunt Bauman - »problem nije kako globalizirati nadmoćnu kulturu, nego kako osigurati komunikaciju i međusobno razumijevanje između kultura« i religija. ${ }^{101}$

Na samom kraju još nešto, ono možda najfinije reformsko u znanosti o kulturi nalazi se u njezinu okretanju književnosti - što je očito u Geertzovu opusu. ${ }^{102}$ Da se ponovno osvrnem na Rortyja: ono što su romantičari izražavali tvrdnjom da je glavna ljudska sposobnost mašta, a ne um, jest zapravo - tvrdi Rorty - ideja da je glavni instrument kulturalne promjene (prema Rortyju, redescription) talent za drugačije izražavanje, a ne za dobru raspravu. ${ }^{103}$ Ono što su politički utopisti slutili nakon Francuske revolucije nije bilo da je trajna, dublja ljudska priroda bila potisnuta neprirodnim ili iracionalnim društvenim institucijama, nego da se mijenjanjem jezika i drugih društvenih praksi može proizvesti ljudska bića koja nikad prije nisu postojala. ${ }^{104}$

Ovdje je korisno prisjetiti se i Julije Kristeve koja smatra da snaga ideologije modernog klasnog društva zavisi o ustaljenim znakovima (otac, država, red, vlasništvo itd.) koje upravo književnost svojim semiotičkim (ono »drugo« jezika) potencijalom može »razarati« pa je stoga ona i analogna revoluciji u političkom životu. ${ }^{105}$ Samo - tu se nalazimo pred opasnom granicom da lijek postane otrov, da zapadnemo u ludilo nezaustavljive semioze.

University Press, Princeton, Oxford 2000., str. 64 .

101

Zygmunt Bauman, Intimations of Postmodernity, Routledge, London 1992., str. 102.

\section{2}

Usp. C. Geertz, Works and Lives. U toj knjizi C. Geertz piše o žanrovima i retoričkim strategijama modernih antropoloških klasika (C. LéviStrauss, B. Malinowski, E. Evans-Pritchard i R. Benedict) koristeći se uvidima američke »nove kritike« (Kenneth Burke) i francuskih poststrukturalista (Roland Barthes i Michel Foucault). Zapravo, u antropološkim radovima osamdesetih godina prošloga stoljeća sve više prevladava svijest da znanost nije iznad već $u$ povijesnom i lingvističkom procesu te da se akademski i književni žanrovi međusobno prožimaju. Naglašava se »literarnost« kao kategorija u koju su protjerani retorika (u ime jasnog značenja), fikcija (u ime fakcije) i subjektivnost (u ime objektivnosti). Usp. James Clifford, George Marcus (ur.), Writing Culture: The Poetics and Politics of Ethnography, University of California Press, Berkeley 1986., str. 5. Fiktivnost ili literarnost više ne znači nešto što je suprotno istini, nego parcijalnost kulturnih i povijesnih istina, način dovođenja u pitanje definitornosti i isključivosti. Kultura/kulture ne shvaćaju se više kao znanstveni »objekt«. Kultura i naše viđenje nje povijesno je određeno i stoga je uvijek osporavano. Usp. ibid., str. 18. Središte, osamdesetih godina već uvelike fragmentiranih istraživačkih projekata, eksperimentiranje je s poluknjiževnim (semiliterary) žanrovima (etnografija) antropološkog diskursa. Usp. G. Marcus, M. M. J. Fischer (ur.), Anthropology as Cultural Critique: An Experimental Moment in the Human Sciences, str. 5.
103

R. Rorty, Contingency, Irony, and Solidarity, str. 7.

104

Ibid. R. Rorty smatra da su »jaki pjesnik« (strong poet) i »utopijski revolucionar« (utopian revolutionary) junaci liberalnog društva. Oni se bune $u$ ime samog društva protiv onih aspekata društva koji odudaraju od njegove vlastite slike o sebi. Tako se dokida razlika između revolucionara i reformista (liberalno društvo ono je čiji se ideali ne ostvaruju silom, nego uvjerenjem; ne revolucijom, nego reformom, slobodnim i otvorenim susretom sadašnjih jezičnih i drugih praksi uz prijedloge novih praksi. Usp. ibid., str. 60 . $\mathrm{Na}$ drugom mjestu R. Rorty napominje da dokidanjem tradicionalnog shvaćanja »objektivnosti« i »znanstvene metode« moći ćemo razumjeti društvenu znanost kao književnost - kao interpretiranje drugih ljudi za nas i tako produbljivanja i proširivanja našeg osjećaja zajedništva. Shvatit ćemo da su nama (obrazovanim, dokonim tvorcima politike Zapada) antropolozi i povjesničari omogućili da bilo koju »egzotičnu vrstu ljudi« vidimo kao da je jedna od nas. Kada nestane shvaćanje o znanju (knowledge) kao predstavljanju (representation), nestat će i poimanje istraživanja kao nečega podijeljenog na sektore. Linija između romana, novinskih članaka i socioloških studija postat će sve nejasnija. Razgraničenje sadržaja ostvarit će se s obzirom na praktične interese, a ne na osnovi pretpostavljenog ontološkog statusa. Usp. R. Rorty, Consequences of Pragmatism, str. 203.

105

Terry Eagleton, Književna teorija, prevela Mia Pervan-Plaves, SNL, Zagreb 1987., str. 202. 


\title{
Krešimir Šimić
}

\section{Interpretative Science of Culture and Postliberal Theology}

\begin{abstract}
When its constitution was attempted in the second half of the nineteenth century, the science of culture (Culturology, L. White) was represented as a reform science. It was a reform in the sense of emancipation concerning metaphysics and theology, but also regarding social progress (E. B. Tylor). The science of culture, which has tried to establish itself as a cohesive place for all socio-humanistic sciences and become reform science, has eventually become the interpretative science (C. Geertz). Interpretative science of culture also has a reformative affinity. After reviewing the nineteenth-century science of culture (anthropology), the paper introduces the fundamental determinants of Geertz's theory of culture and postliberal liberal theology, primarily based on Geertz. Finally, the paper reveals the reform potential of interpretative science of culture and postliberal theology.
\end{abstract}

\section{Key words}

science of culture, interpretative science, Clifford Geertz, postliberal theology, reform 